\title{
Hydrogeochemical characteristics and age dating of groundwater in the Quaternary and Nubian aquifer systems in Wadi Qena, Eastern Desert, Egypt
}

\author{
A. A. Abdel Moneim ${ }^{1}$ E. M. Seleem ${ }^{2}$ S. A. Zeid ${ }^{2}$ S. G. Abdel Samie ${ }^{3}$. \\ Sameh $\mathrm{Zaki}^{4} \cdot$ A. Abu El-Fotoh ${ }^{5}$
}

Received: 28 June 2015/Accepted: 4 August 2015/Published online: 9 September 2015

(c) Springer International Publishing 2015

\begin{abstract}
The study area is a part of Wadi Qena, Eastern Desert. It is one of the largest promising areas for development in Upper Egypt. A new desert road was constructed to join Upper Egypt to the Red Sea, passing through the wadi. This accelerates the forms of development in the middle part of the wadi. The development focused on new cultivation farms established through the drilling of tens of wells to extract groundwater for land reclamation. The present study focused on the assessment of groundwater quality, its origin and suitability for drinking and agricultural purposes. This is made through the chemical analysis of a number of groundwater samples. A comparison of the water quality with the standard of drinking and irrigation water quality revealed that the water was not suitable for drinking purposes and could be used for high salt-tolerant crops. The evaluation of the saturation index (SI) of the water sample indicted that water was oversaturated with respect to iron minerals and undersaturated with carbonate minerals The analysis of the isotope data $\left(\delta^{18} \mathrm{O}\right.$ and $\left.\delta^{2} \mathrm{H}\right)$ of the water samples indicated that water samples of wells more than $500 \mathrm{~m}$ deep were mainly of Nubian sources (old water) and could be mixed by recharge from the Quaternary
\end{abstract}

\footnotetext{
A. A. Abdel Moneim

ahmed_aziz9791@science.sohag.edu.eg

1 Geology Department, Faculty of Science, Sohag University, Sohâg, Egypt

2 Geology Department, Faculty of Science, Al Azhar University, Assuit Branch, Cairo, Egypt

3 National Center for Nuclear Safety and Radiation Control, Cairo, Egypt

4 The General Authority of Mineral Resources, Cairo, Egypt

5 The Research Institute of Groundwater Research, Cairo, Egypt
}

water. The other water samples showed that the origin of water was Quaternary, while the water samples collected from the shallow pits showed that water originated from the relatively fresh water. The study revealed that the old Nubian water was not renewable and should be managed properly to sustain the existing and proposed development.

Keywords Hydrogeochemisty - Groundwater quality . Saturation index - Environmental isotope - Age dating · Wadi Qena

\section{Introduction}

Wadi Qena is one of the longest wadis in the Eastern Desert of Egypt. It is a promising dry valley in the central Eastern Desert. The wadi is the unique obsequent wadi in the Eastern Desert of Egypt. It collects sporadic rainfalls from many effluents, which join the main stream along the $270 \mathrm{~km}$ course from the east to southeast. The wadi extends from north to south with an average east-west average width of $40 \mathrm{~km}$. It is located at the northwest of Qena Governorate and extends between Qena City and Hurgada at the Red Sea, covering a surface area of about $18,000 \mathrm{~km}^{2}$ (Fig. 1).

Many previous studies have been carried out to investigate the geologic, geomorphological and hydrologic features of the wadi. Aggour (1997) investigated the impacts of geomorphological and geological conditions of the wadi. Gheith and Sultan (2002) estimated the probable groundwater recharge rate for alluvial aquifers of the Eastern Desert (i.e., Wadi Qena) from the sporadic precipitation over the Red Sea hills (during the 1994 rain storm events) as $49 \times 10^{6} \mathrm{~m}^{3}$, which indicates the promising nature of the Quaternary alluvial aquifer in the area. The hydraulic 


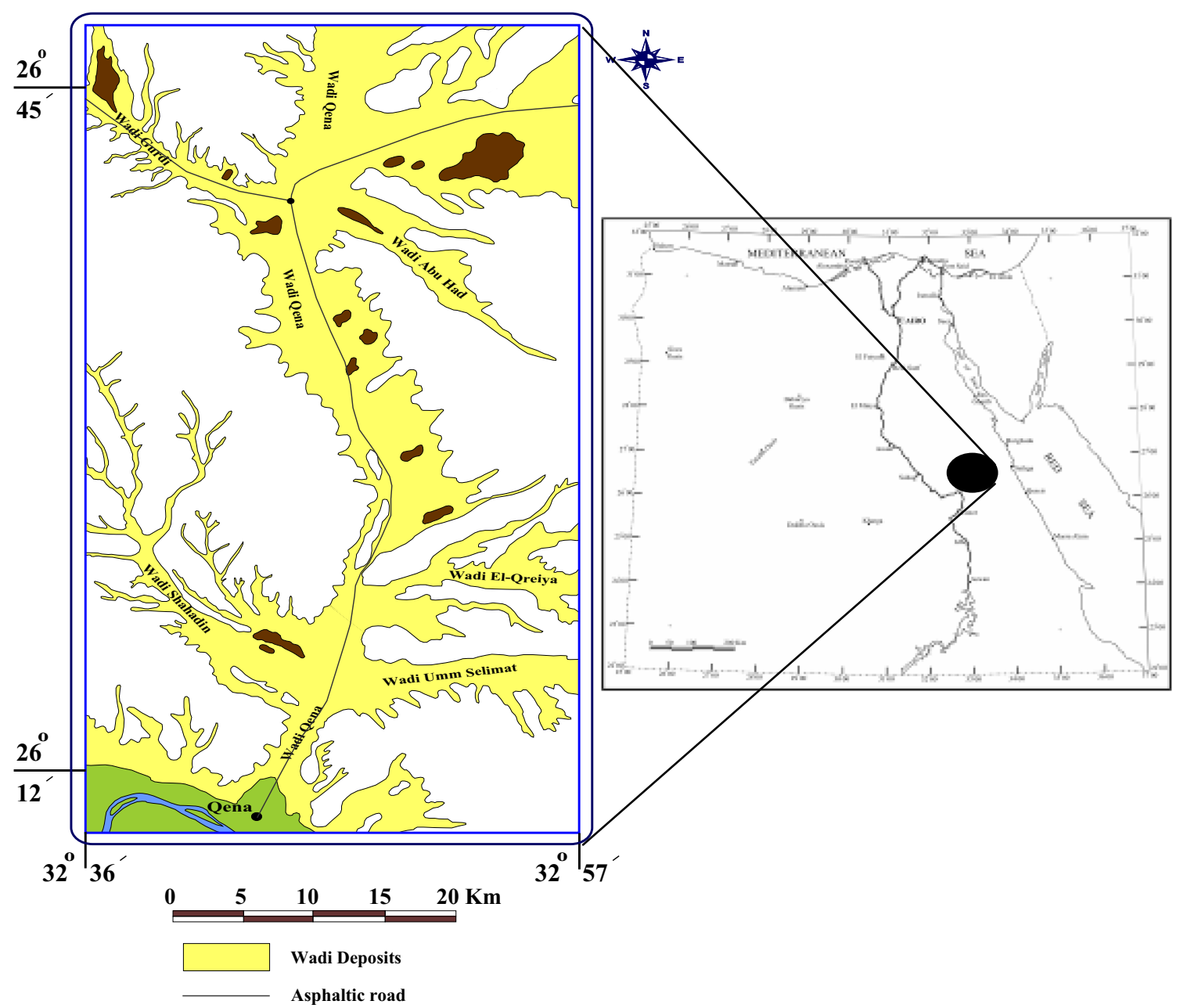

Fig. 1 Location map of the study area showing the new road

interconnection between the Quaternary aquifer and the underlying Nubian aquifer system in Wadi Qena is favored through the structural region (Elewa et al. 2000, 2006, 2011). Using isotopic and geochemical analysis along with field and remote sensing data, Sultan et al. (2000) showed that the discharge of the Nubian aquifer occurs on a large scale primarily through the deep-seated fault system, and the ascending groundwater discharges into the relatively thick alluvial aquifers proximal to the fault complex that define the River Nile. Based on the pumping test data, Elewa and Abu El Ella (2011)concluded that the hydrogeological system in the wadi is made of four layers: the upper layer contains unconfined Quaternary wadi deposits, the second and the third are considered as aquiclude and the bottom layers is the Nubian aquifer system followed by the basement rocks.

The preset study is focused on the description of the hydrogeochemical properties of groundwater in the central part of Wadi Qena. Samples were collected from the available groundwater wells and subjected to chemical analysis for the major and minor elements and environmental isotopes. The study aims to evaluate the origin of groundwater and its suitability for drinking and irrigation purposes. The saturation of groundwater with carbonate minerals was investigated. To accomplish that, the following stages were established:

1. Field measurements of the unstable parameters such as $\mathrm{pH}, \mathrm{EC}, \mathrm{TDS}$ and the collection of water samples from all available wells in the area were obtained (26 samples as shown in Fig. 2). These samples were subjected to detailed chemical analysis for the anions and cations at the laboratory of Applied Geochemistry in Faculty of Science, Sohag University. The results were analyzed and represented in the different graphs for identification of water characteristics, origin and suitability for different purposes.

2. The thermodynamic stability of groundwater was studied using the saturation index (SI) to define the saturation status regarding the carbonate and iron minerals. 


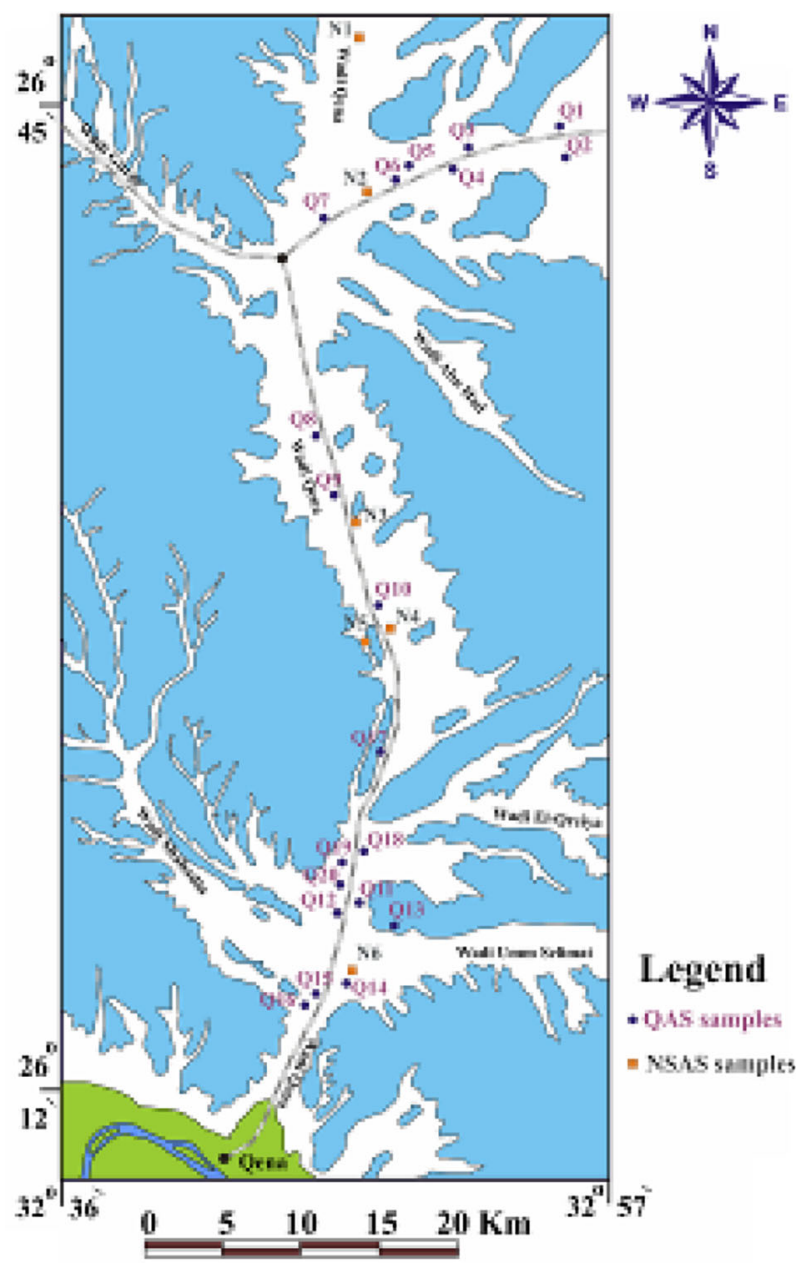

Fig. 2 Location map of groundwater samples in the study area

3. Twenty-two water samples ware subjected to environmental isotope analysis to define the relative age of groundwater in the area. The analyses were carried out at the National Center for Nuclear Safety and Radiation Control, Atomic Energy Authority in Cairo.

\section{Geology of the area}

Many publications are available on the geology of Wadi Qena, among which are those by Ghorab (1956), Youssef (1957), Said (1960), Ghorab (1961), Said (1962), Awad and Ghobrial (1965), Said (1971, 1975, 1981); Hendriks and Kallenbach (1986), Hendriks et al. (1987), Bandel et al. (1987), Hermina et al. (1989), Hermina, (1990), Said (1990), Abdallah et al. (1992), Issawi et al. (1999), Abdel Moneim (2005) and Wilmsen and Nagm (2012).

The sedimentary succession of Wadi Qena generally ranges from Paleozoic to Quaternary deposits (Figs. 3, 4).
Most of the Paleozoic rocks are non-marine and well represented in the northern part of the wadi. The distribution of the Paleozoic sediments was more or less controlled by older pre-Cenomanian structural events (Said, 1990; Issawi et al. 1999). The first marine influence is documented in the central and northern parts of Wadi Qena which occur within the Upper Lower Cretaceous deposits. The marine transgression was continued with some phases of regressions later on during the Late Cretaceous and Tertiary. This resulted in the deposition of the most sedimentary rocks of Wadi Qena. Table 1 summarizes the existing formations, age and lithology of the recorded geologic units in Wadi Qena.

Structurally, Wadi Qena anticline represents one of the oldest systems in the stable shelf of Egypt (Hume 1929; Sandford 1929; Said 1962; Billings 1954; Stern and Hedge 1985; CONOCO 1987; EGSMA 1983, 2006, El Gaby et al. 1988; Aggour 1997; Abdel Ghany 2011). It has a great amplitude and gentle dip and plunges southward. Its axis runs almost in the north-south direction and coincides with the Wadi Qena main trunk. The concerned anticline covers most of the Wadi Qena hydrographic basin and is displayed in the area between latitudes $26^{\circ} 30^{\prime}$ and $28^{\circ} 00^{\prime} \mathrm{N}$ for a distance of more than $200 \mathrm{~km}$.

\section{Hydrogeology of the area}

Most of the hydrogeological studies that have been carried out in Wadi Qena were focused mainly on the downstream of the wadi, among these are those by El Ramly (1972), Gomaa (1992), Thorweihe and Heinl (1993), Aggour and Sadek (2001), Assiut University (2001), Yehia (2001), Abdel Moneim (2005) and Seleem (2014). The review of pervious publications indicated that groundwater in Wadi Qena and its surroundings exists with different potentials in six aquifers under different hydrogeologic conditions. These units are: Quaternary alluvium aquifer, Pliocene sandstone aquifer, Lower Maastrichtian phosphate aquifer, Companion marl aquifer, Turonian-Santonian sandstone aquifer, Precambrian basement complex aquifer. Water in these aquifers exist under free water table conditions expected that of the last one (known as Nubain aquifer system) where confined conditions are prevaling. Abdel Moneim (2005) revealed that the most promising aquifers are the (from quantity point of view) Quaternary and the Nubian water-bearing formations.

The Quaternary alluvial deposits are formed of sand, gravel and boulders, filling the courses of the hydrographic basins. They have lateral and vertical variations in the lithological composition according to the dominated rock exposures in the hydrographic basins. The Quaternary 
Fig. 3 A geologic map of Wadi Qena area (after CONOCO 1987; EGSMA 1983, 2006)

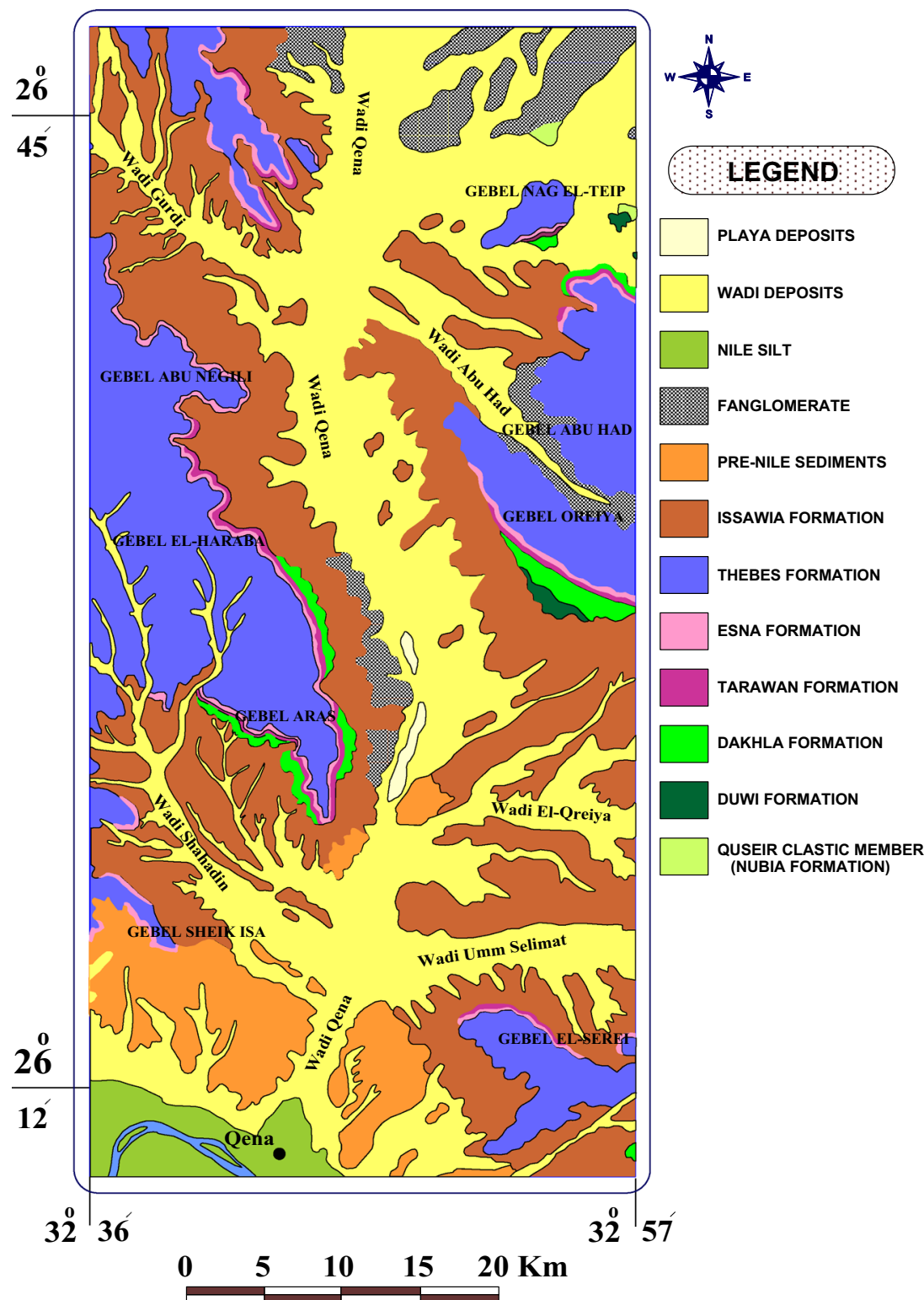

alluvium aquifer is affected by different environmental conditions, representing the areal variation of thickness, texture, composition and water chemistry. The thickness of the Quaternary alluvial deposits varies in Wadi Qena from place to place due to the undulation of subsurface strata and the effective erosion of surface layers in other places. In general, the thickness increases downstream of the wadi and reaches $100 \mathrm{~m}$ at the downstream (Seleem 2013).

Groundwater in the Nubian aquifer occurs under confined condition and the exploited part lies below the mean sea level. The overlying impermeable Quseir shale is considered as the confining bed overlying the sandstone series. The depth to the Nubian aquifer differs from one locality to another and depends on the geological condition in the area. It ranges from 300 to $500 \mathrm{~m}$ below the ground surface with an average thickness of $350 \mathrm{~m}$ (Abdel Moneim 2005). The flow of the groundwater in the Nubian sandstone aquifer in Wadi Qena is defined to be from the northeast to southeast (Aggour 1997).

\section{Geochemsity of groundwater}

The evaluation of the geochemical characteristics of groundwater in the study area is based on the detailed chemical analysis of the 26 water samples (20 for the Quaternary aquifer system (QAS) and 6 for Nubian sandstone aquifer system (NSAS). The differentiation between 


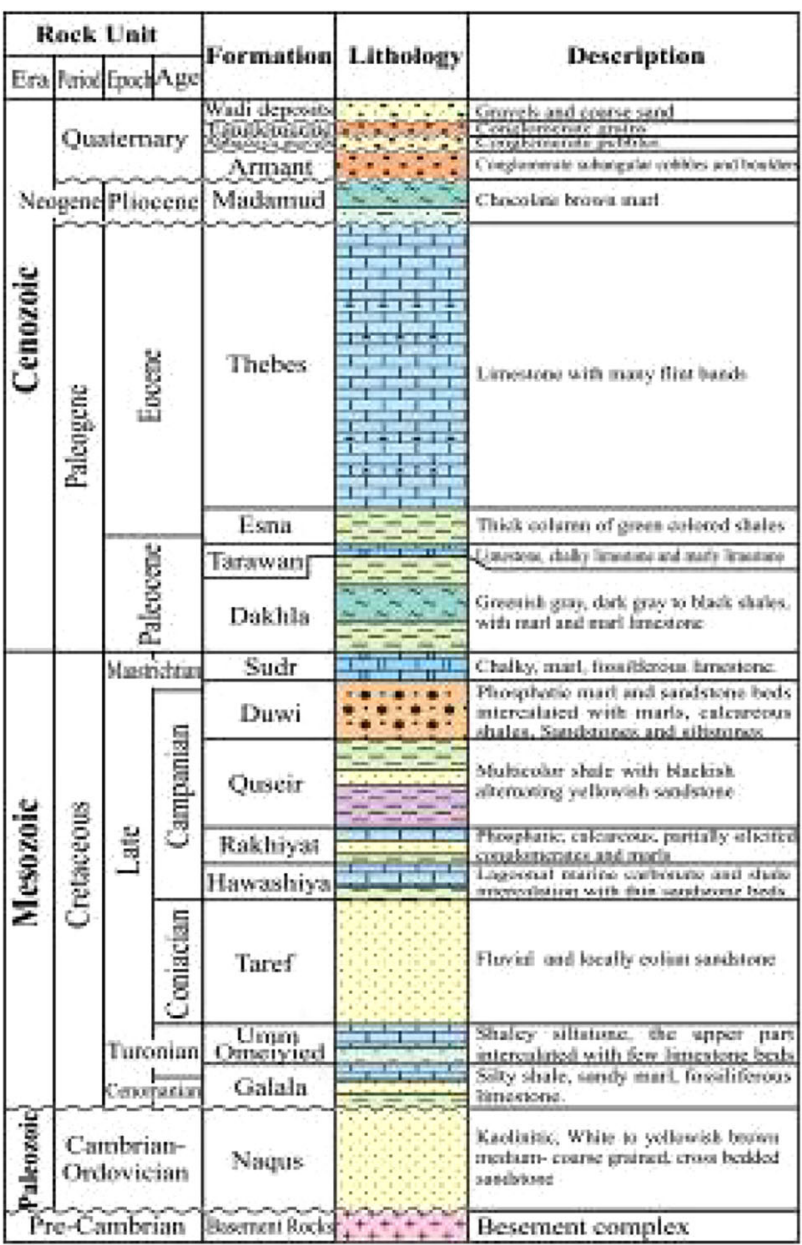

Fig. 4 Lithostratigraphic columnar section of Wadi Qena (after CONOCO 1987; EGSMA 1983, 2006)

the QAS and the NSAS is based on the depth of sampling and description of the lithologic logs of the wells in relation to the existing geologic conditions in addition to the review of the available literature. The result of the chemical analysis is given in Tables 2 and 3. The following is the description of the main findings.

\section{Total dissolved solids (TDS)}

The TDS in QAS varies from $1183 \mathrm{ppm}$ (well no. Q4) to 5506 ppm (well no. Q18), while its varies from 1496 ppm (well no. N6) to $1715 \mathrm{ppm}$ (well no. N1) for the NSAS (Figs. 5, 6), respectively. The iso-salinity distribution map of QAS (Fig. 5) and NSAS (Fig. 6) shows a general increase toward the south of the study area which may reflect a continuous recharge from the rainfall. The increase of the TDS in both aquifers is in accordance with the direction of groundwater flow, reflecting the impact of the leachate effects of water-bearing formations.

\section{Distribution of major ions}

The most common elements found in groundwater include four cations, calcium, magnesium, sodium and potassium, and four anions, bicarbonate, carbonate, sulfate and chloride. These anions and cations are present in the water in detectable amounts and govern its physical and chemical characteristics. The source of sodium in water depends on the rock type through which the water moved. The sodium content of the groundwater in the QAS in the study area ranges from about $197 \mathrm{ppm}$ (well no. Q4) to $1210 \mathrm{ppm}$ (well no. Q20) (Table 2, Fig. 7), and ranges from about 345 ppm (well no. N4) to 411 ppm (well no. N1) for NSAS (Table 3, Fig. 8). Generally, in QAS the sodium content increases from the north to the south regions. On the other hand, the sodium content of NSAS increases from the south to the north regions, probably due to the impact of the lithology of the NSAS.

Calcium occurs in carbonates such as limestone and dolomite and in sulfate such as gypsum and anhydrite. For QAS, the maximum measured calcium concentration value in the study area $(567 \mathrm{ppm})$ was recorded in sample no. Q17, while the lowest value (55 ppm) was recorded in sample no. Q6 (Table 2). In NSAS, the maximum measured calcium concentration value (115 ppm) was recorded in sample no. N1, while the lowest value ( $88 \mathrm{ppm})$ was recorded in sample no. N6 (Table 3). Generally, in QAS the calcium content increases from the north to south regions and reaches its higher values in the south (well no. Q17). On the other hand, the calcium content of NSAS increases from the south to the north regions as the aquifers approached the calcium carbonates of the Thebes Formation.

Magnesium is abundant in rocks and soil containing limestone, dolomites and gypsum. The maximum measured magnesium concentration value $(183 \mathrm{ppm})$ was recorded in sample no. Q14 and Q15, while the lowest value (18 ppm) was recorded in sample no. Q4 for QAS (Table 2). For NSAS, the maximum measured magnesium concentration value $(58 \mathrm{ppm})$ was recorded in sample no. $\mathrm{N} 3$, while the lowest value (46 ppm) was recorded in sample no. N6 for NSAS (Table 3). The magnesium content in QAS increases from north to south with the flow direction, while it increases in the reverse direction for NSAS. This may be attributed to the impacts of the aquifer lithology.

Potassium in groundwater is generated from the silicate rocks minerals that contain potassium as the potash feldspars, orthoclase and microcline. Potassium salts are less readily available as solution in water in the clastic sediments. Potassium represents the lowest cations in the groundwater samples. In the study area, the potassium content in groundwater ranged between $4 \mathrm{ppm}$ (well no. 
Table 1 Summary of the geologic units recorded in Wadi Qena

\begin{tabular}{|c|c|c|}
\hline Formation & Age & Lithologic description \\
\hline Quaternary deposits & Quaternary & Wadi deposits, detritus, sand and pebbles \\
\hline Madamud formation & Pliocene & Chocolate brown marls \\
\hline Thebes formation & Eocene & Limestone \\
\hline Esna formation & Paleocene-Eocene & Thick column of green-colored shales \\
\hline Tarawan formation & Paleocene & Chalk and chalky limestone \\
\hline Dakhla formation & Maastrichtian-Paleocene & Shale succession \\
\hline Sudr formation & Maastrichtian & Chalky deposits \\
\hline Duwi formation & Late Campanian & Phosphate unit \\
\hline Quseir formation & Middle Campanian & Multicolored shale with blackish alternating yellowish sandstone \\
\hline Rakhiyat formation & Early Campanian & Phosphatic, calcareous, partially silicified conglomerates and marls \\
\hline Hawashiya formation & Early Campanian & Lagoonal marine carbonate and shale, locally intercalated with thin sandstone beds \\
\hline Taref formation & Coniacian & Fluvial and locally eolian sandstone \\
\hline $\begin{array}{l}\text { Umm Omeiyid } \\
\text { formation }\end{array}$ & Middle-Late Turonian & Shaley siltstone with thin, medium-grained sandstone intercalations \\
\hline Galala formation & $\begin{array}{l}\text { Late Cenomanian-Early } \\
\text { Turonian }\end{array}$ & Silty shale, sandy marl and fossiliferous limestone beds \\
\hline Naqus formation & $\begin{array}{l}\text { Ordovician-Early } \\
\text { Carboniferous }\end{array}$ & $\begin{array}{l}\text { Kaolinitic, white to yellowish brown, medium- to coarse-grained, large-scale cross- } \\
\text { bedded sandstone }\end{array}$ \\
\hline Basement & Pre-Cambrian & Crystalline igneous and metamorphic rocks \\
\hline
\end{tabular}

Q4 and Q7) to 14 ppm (well no. Q18) for QAS (Table 2) and from 5 ppm (well no. N6) to 12 ppm (well no. N1) for NSAS (Table 3).

Chloride in groundwater may originate in evaporate deposits or from seawater trapped in sediments during their deposition. Other sources of chloride include solution of dry atmospheric fallout, municipal sewage and industrial wastes (does not exist in the study area). With regard to the distribution of chloride content in the groundwater of the study area, it ranges from about 173 ppm (well no. Q4) to 2142 ppm (well no. Q18) for QAS (Table 2), while in NSAS the chloride concentration varies between 566 and $649 \mathrm{ppm}$. Generally, the chloride content for QAS increases to the south direction (Fig. 9). On the other hand, the chloride content for NSAS increases at the north direction (Fig. 10).

Bicarbonate and carbonate ions in groundwater exist due to dissolved carbon dioxide in rains which, as it enters the soil, dissolves more carbon dioxide. The bicarbonate content of the groundwater in the QAS in the study area ranges from $89 \mathrm{ppm}$ (well no. Q20) to $578 \mathrm{ppm}$ (well no. Q14) (Table 2) and from $130 \mathrm{ppm}$ (well no. N3) to $172 \mathrm{ppm}$ (well no. N6) for NSAS (Table 3). Generally, in QAS the bicarbonate content increases at the southern part of the study area and reaches its higher values (well no. Q14), while the lower value is recorded at the northern part, where higher rainfall in this area has taken place. On the other hand, the bicarbonate content for NSAS increases at the southern part of the study area.
Sulfate is useful for understanding oxidation-reduction conditions in groundwater and for predicting the fate of contaminants, such as industrial solvent. With regard to the distribution of sulfate content in the groundwater of the study area, it ranges from about $251 \mathrm{ppm}$ (well no. Q6) to 1781 ppm (well no. Q15) for QAS (Table 2), while in NSAS it varies between 237 and 338 ppm. Generally, the sulfate content for QAS increases to the south of the study area; this may be attributed to the effect of soil salinity. On the other hand, the sulfate content for NSAS increases toward the north of the study area.

\section{Major ion relationships in QAS and NSAS}

The ion ratios enable possible determination of the origin of water and detection of the hydrochemical processes acted in water, such as contamination, mixing and ion exchange. Such relationships could be studied through the calculation of the hydrochemical coefficients of the water samples, characterized to the two present aquifers in the study area. A summary of the calculation of the hydrochemical parameters is given in Table 4.

The $\mathrm{rNa}^{+} / \mathrm{rCl}^{-}$coefficient is of special importance; it is used in detecting the groundwater origin (marine or meteoric). In the sea water, this coefficient is less than the unity while it attain more than unity in the meteoric water. In the study area the values of $\mathrm{rNa}^{+} / \mathrm{rCl}^{-}$coefficient for $25 \%$ of the samples collected from the QAS have less than one while the rest of samples in the QAS $(75 \%)$ have more 
Table 2 Chemical analysis data of the collected water samples from QAS in the study area

\begin{tabular}{|c|c|c|c|c|c|c|c|c|c|c|}
\hline \multirow[t]{2}{*}{ Sample no. } & & \multicolumn{3}{|c|}{ Location } & \multirow[t]{2}{*}{ Units } & \multirow[t]{2}{*}{$\mathrm{Ca}^{++}$} & \multirow[t]{2}{*}{$\mathrm{Mg}^{++}$} & \multirow[t]{2}{*}{$\mathrm{Na}^{+}$} & \multirow[t]{2}{*}{$\mathrm{K}^{+}$} & \multirow{2}{*}{$\begin{array}{l}\text { Sum } \\
\text { Cat. }\end{array}$} \\
\hline & & Deg. & Min & $\mathrm{Sec}$ & & & & & & \\
\hline \multirow[t]{3}{*}{ Q1 } & $\mathrm{N}$ & 26 & 44 & 12.7 & $\mathrm{mg} / \mathrm{l}$ & 192.0 & 35.0 & 390.0 & 10.9 & \\
\hline & & & & & meq/l & 9.6 & 2.9 & 17.0 & 0.3 & 29.7 \\
\hline & $\mathrm{E}$ & 32 & 55 & 12.1 & e $\%$ & 32.3 & 9.7 & 57.1 & 0.9 & \\
\hline \multirow[t]{3}{*}{ Q2 } & $\mathrm{N}$ & 26 & 42 & 25.4 & $\mathrm{mg} / \mathrm{l}$ & 180.0 & 30.8 & 386.0 & 8.9 & \\
\hline & E & 32 & 55 & 15.5 & meq/l & 9.0 & 2.5 & 16.8 & 0.2 & 28.5 \\
\hline & & & & & e $\%$ & 31.5 & 8.9 & 58.8 & 0.8 & \\
\hline \multirow[t]{3}{*}{ Q3 } & $\mathrm{N}$ & 26 & 43 & 34.4 & $\mathrm{mg} / \mathrm{l}$ & 165.2 & 23.2 & 312.0 & 6.1 & \\
\hline & & & & & meq/l & 8.2 & 1.9 & 13.6 & 0.2 & 23.9 \\
\hline & $\mathrm{E}$ & 32 & 51 & 20 & e $\%$ & 34.5 & 8.0 & 56.8 & 0.7 & \\
\hline \multirow[t]{3}{*}{ Q4 } & $\mathrm{N}$ & 26 & 43 & 17.9 & $\mathrm{mg} / \mathrm{l}$ & 151.0 & 18.3 & 197.0 & 4.1 & \\
\hline & & & & & meq/l & 7.5 & 1.5 & 8.6 & 0.1 & 17.7 \\
\hline & $\mathrm{E}$ & 32 & 50 & 59.5 & e $\%$ & 42.5 & 8.5 & 48.4 & 0.6 & \\
\hline \multirow[t]{3}{*}{ Q5 } & $\mathrm{N}$ & 26 & 42 & 56 & $\mathrm{mg} / \mathrm{l}$ & 67.3 & 25.0 & 378.0 & 5.4 & \\
\hline & & & & & $\mathrm{meq} / \mathrm{l}$ & 3.4 & 2.1 & 16.4 & 0.1 & 22.0 \\
\hline & $\mathrm{E}$ & 32 & 49 & 17.9 & e $\%$ & 15.3 & 9.4 & 74.8 & 0.6 & \\
\hline \multirow[t]{3}{*}{ Q6 } & $\mathrm{N}$ & 26 & 42 & 29 & $\mathrm{mg} / \mathrm{l}$ & 55.0 & 27.4 & 321.0 & 5.1 & \\
\hline & & & & & $\mathrm{meq} / \mathrm{l}$ & 2.7 & 2.3 & 14.0 & 0.1 & 19.1 \\
\hline & $\mathrm{E}$ & 32 & 48 & 49.2 & e $\%$ & 14.4 & 11.8 & 73.1 & 0.7 & \\
\hline \multirow[t]{3}{*}{ Q7 } & $\mathrm{N}$ & 26 & 41 & 10.7 & $\mathrm{mg} / \mathrm{l}$ & 97.3 & 28.5 & 330.0 & 4.0 & \\
\hline & & & & & $\mathrm{meq} / \mathrm{l}$ & 4.9 & 2.3 & 14.4 & 0.1 & 21.7 \\
\hline & $\mathrm{E}$ & 32 & 46 & 2.7 & e $\%$ & 22.4 & 10.8 & 66.3 & 0.5 & \\
\hline \multirow[t]{3}{*}{ Q8 } & $\mathrm{N}$ & 26 & 33 & 54.4 & $\mathrm{mg} / \mathrm{l}$ & 100.8 & 22.7 & 430.0 & 5.0 & \\
\hline & & & & & meq/l & 5.0 & 1.9 & 18.7 & 0.1 & 25.7 \\
\hline & $\mathrm{E}$ & 32 & 46 & 7.3 & e $\%$ & 19.5 & 7.2 & 72.7 & 0.5 & \\
\hline \multirow[t]{3}{*}{ Q9 } & $\mathrm{N}$ & 26 & 31 & 57.4 & $\mathrm{mg} / \mathrm{l}$ & 123.4 & 32.1 & 442.0 & 6.2 & \\
\hline & & & & & $\mathrm{meq} / \mathrm{l}$ & 6.2 & 2.6 & 19.2 & 0.2 & 28.2 \\
\hline & $\mathrm{E}$ & 32 & 46 & 36.8 & e $\%$ & 21.8 & 9.4 & 68.2 & 0.6 & \\
\hline \multirow[t]{3}{*}{ Q10 } & $\mathrm{N}$ & 26 & 28 & 14.9 & $\mathrm{mg} / \mathrm{l}$ & 92.7 & 73.4 & 470.0 & 8.8 & \\
\hline & & & & & $\mathrm{meq} / \mathrm{l}$ & 4.6 & 6.0 & 20.4 & 0.2 & 31.3 \\
\hline & $\mathrm{E}$ & 32 & 47 & 57.6 & e $\%$ & 14.8 & 19.3 & 65.3 & 0.7 & \\
\hline \multirow[t]{3}{*}{ Q11 } & $\mathrm{N}$ & 26 & 18 & 17.9 & $\mathrm{mg} / \mathrm{l}$ & 402.0 & 172.0 & 935.0 & 10.4 & \\
\hline & & & & & $\mathrm{meq} / \mathrm{l}$ & 20.1 & 14.1 & 40.7 & 0.3 & 75.1 \\
\hline & $\mathrm{E}$ & 32 & 47 & 24.8 & e $\%$ & 26.7 & 18.8 & 54.1 & 0.4 & \\
\hline \multirow[t]{3}{*}{ Q12 } & $\mathrm{N}$ & 26 & 17 & 57.2 & $\mathrm{mg} / \mathrm{l}$ & 315.0 & 130.0 & 1020.0 & 9.0 & \\
\hline & & & & & $\mathrm{meq} / \mathrm{l}$ & 15.7 & 10.7 & 44.4 & 0.2 & 71.0 \\
\hline & $\mathrm{E}$ & 32 & 46 & 40.2 & e $\%$ & 22.1 & 15.0 & 62.5 & 0.3 & \\
\hline Q13 & $\mathrm{N}$ & 26 & 17 & 42.5 & $\mathrm{mg} / \mathrm{l}$ & 356.0 & 92.0 & 1160.0 & 9.9 & \\
\hline & & & & & $\mathrm{meq} / \mathrm{l}$ & 17.8 & 7.6 & 50.5 & 0.3 & 76.0 \\
\hline & $\mathrm{E}$ & 32 & 48 & 48.3 & e $\%$ & 23.4 & 9.9 & 66.4 & 0.3 & \\
\hline Q14 & $\mathrm{N}$ & 26 & 15 & 24.6 & $\mathrm{mg} / \mathrm{l}$ & 360.0 & 183.0 & 1180.0 & 12.5 & \\
\hline & & & & & $\mathrm{meq} / \mathrm{l}$ & 18.0 & 15.0 & 51.3 & 0.3 & 84.7 \\
\hline & $\mathrm{E}$ & 32 & 47 & 0.1 & e $\%$ & 21.2 & 17.8 & 60.6 & 0.4 & \\
\hline Q15 & $\mathrm{N}$ & 26 & 14 & 56.3 & $\mathrm{mg} / \mathrm{l}$ & 378.5 & 182.8 & 1160.0 & 12.5 & \\
\hline & & & & & $\mathrm{meq} / 1$ & 18.9 & 15.0 & 50.5 & 0.3 & 84.7 \\
\hline & E & 32 & 45 & 37.7 & e $\%$ & 22.3 & 17.7 & 59.6 & 0.4 & \\
\hline
\end{tabular}


Table 2 continued

\begin{tabular}{|c|c|c|c|c|c|c|c|c|c|c|}
\hline \multirow[t]{2}{*}{ Sample no. } & & \multicolumn{3}{|c|}{ Location } & \multirow[t]{2}{*}{ Units } & \multirow[t]{2}{*}{$\mathrm{Ca}^{++}$} & \multirow[t]{2}{*}{$\mathrm{Mg}^{++}$} & \multirow[t]{2}{*}{$\mathrm{Na}^{+}$} & \multirow[t]{2}{*}{$\mathrm{K}^{+}$} & \multirow{2}{*}{$\begin{array}{l}\text { Sum } \\
\text { Cat. }\end{array}$} \\
\hline & & Deg. & Min & $\mathrm{Sec}$ & & & & & & \\
\hline \multirow[t]{3}{*}{ Q16 } & $\mathrm{N}$ & 26 & 15 & 12 & $\mathrm{mg} / 1$ & 371.0 & 180.0 & 1150.0 & 11.9 & \\
\hline & & & & & meq/1 & 18.5 & 14.8 & 50.0 & 0.3 & 83.6 \\
\hline & $\mathrm{E}$ & 32 & 45 & 55 & e $\%$ & 22.1 & 17.7 & 59.8 & 0.4 & \\
\hline \multirow[t]{3}{*}{ Q17 } & $\mathrm{N}$ & 26 & 23 & 30.2 & $\mathrm{mg} / \mathrm{l}$ & 567.0 & 141.0 & 1160.0 & 11.6 & \\
\hline & & & & & meq/l & 28.3 & 11.6 & 50.5 & 0.3 & 90.6 \\
\hline & $\mathrm{E}$ & 32 & 48 & 15.7 & e $\%$ & 31.2 & 12.8 & 55.7 & 0.3 & \\
\hline \multirow[t]{3}{*}{ Q18 } & $\mathrm{N}$ & 26 & 19 & 51.4 & $\mathrm{mg} / \mathrm{l}$ & 516.0 & 157.0 & 1210.0 & 13.9 & \\
\hline & & & & & meq/l & 25.7 & 12.9 & 52.6 & 0.4 & 91.6 \\
\hline & $\mathrm{E}$ & 32 & 47 & 11.8 & e $\%$ & 28.1 & 14.1 & 57.4 & 0.4 & \\
\hline \multirow[t]{3}{*}{ Q19 } & $\mathrm{N}$ & 26 & 19 & 36.7 & $\mathrm{mg} / \mathrm{l}$ & 484.0 & 151.0 & 1020.0 & 11.1 & \\
\hline & & & & & meq/l & 24.2 & 12.4 & 44.4 & 0.3 & 81.2 \\
\hline & $\mathrm{E}$ & 32 & 46 & 38.6 & e $\%$ & 29.7 & 15.3 & 54.6 & 0.4 & \\
\hline \multirow[t]{3}{*}{ Q20 } & $\mathrm{N}$ & 26 & 18 & 52 & $\mathrm{mg} / \mathrm{l}$ & 480.6 & 139.7 & 1014.0 & 11.9 & \\
\hline & & & & & meq/l & 24.0 & 11.5 & 44.1 & 0.3 & 79.9 \\
\hline & $\mathrm{E}$ & 32 & 46 & 41.9 & e $\%$ & 30.0 & 14.4 & 55.2 & 0.4 & \\
\hline
\end{tabular}

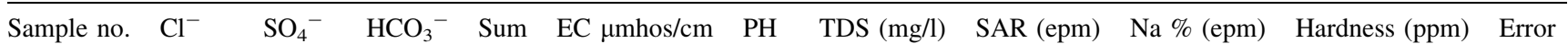
Ani.

\begin{tabular}{|c|c|c|c|c|c|c|c|c|c|c|c|}
\hline \multirow[t]{3}{*}{ Q1 } & 592.0 & 428.0 & 192.0 & & 2835 & 6.80 & 1840 & 6.80 & 57.12 & 622.89 & 1.64 \\
\hline & 16.7 & 8.9 & 3.1 & 28.7 & & & & & & & \\
\hline & 58.1 & 31.0 & 11.0 & & & & & & & & \\
\hline \multirow[t]{3}{*}{ Q2 } & 541.0 & 439.5 & 181.0 & & 2721 & 6.90 & 1767 & 7.00 & 58.85 & 575.69 & 2.09 \\
\hline & 15.3 & 9.1 & 3.0 & 27.4 & & & & & & & \\
\hline & 55.7 & 33.4 & 10.8 & & & & & & & & \\
\hline \multirow[t]{3}{*}{ Q3 } & 412.0 & 457.3 & 152.0 & & 2347 & 6.80 & 1528 & 6.02 & 56.84 & 507.53 & 0.54 \\
\hline & 11.6 & 9.5 & 2.5 & 23.6 & & & & & & & \\
\hline & 49.2 & 40.3 & 10.6 & & & & & & & & \\
\hline \multirow[t]{3}{*}{ Q4 } & 172.7 & 468.4 & 172.0 & & 1810 & 6.80 & 1183 & 4.03 & 48.38 & 451.92 & 0.79 \\
\hline & 4.9 & 9.7 & 2.8 & 17.4 & & & & & & & \\
\hline & 27.9 & 55.9 & 16.2 & & & & & & & & \\
\hline \multirow[t]{3}{*}{ Q5 } & 420.0 & 296.0 & 196.0 & & 2129 & 7.80 & 1388 & 9.99 & 74.76 & 270.77 & 1.81 \\
\hline & 11.8 & 6.2 & 3.2 & 21.2 & & & & & & & \\
\hline & 55.8 & 29.0 & 15.2 & & & & & & & & \\
\hline \multirow[t]{3}{*}{ Q6 } & 413.2 & 251.0 & 118.6 & & 1822 & 6.90 & 1191 & 8.83 & 73.14 & 249.84 & 0.72 \\
\hline & 11.7 & 5.2 & 1.9 & 18.8 & & & & & & & \\
\hline & 61.9 & 27.7 & 10.3 & & & & & & & & \\
\hline \multirow[t]{3}{*}{ Q7 } & 463.7 & 270.0 & 130.4 & & 2029 & 6.90 & 1324 & 7.57 & 66.30 & 359.77 & 1.93 \\
\hline & 13.1 & 5.6 & 2.1 & 20.8 & & & & & & & \\
\hline & 62.8 & 27.0 & 10.3 & & & & & & & & \\
\hline \multirow[t]{3}{*}{ Q8 } & 591.6 & 324.0 & 93.5 & & 2409 & 6.90 & 1568 & 10.08 & 72.71 & 344.59 & 1.52 \\
\hline & 16.7 & 6.7 & 1.5 & 25.0 & & & & & & & \\
\hline & 66.9 & 27.0 & 6.1 & & & & & & & & \\
\hline \multirow[t]{3}{*}{ Q9 } & 604.9 & 402.5 & 133.9 & & 2687 & 6.90 & 1745 & 9.17 & 68.22 & 440.01 & 1.00 \\
\hline & 17.1 & 8.4 & 2.2 & 27.6 & & & & & & & \\
\hline & 61.7 & 30.3 & 7.9 & & & & & & & & \\
\hline \multirow[t]{3}{*}{ Q10 } & 654.0 & 490.0 & 168.0 & & 3018 & 6.90 & 1957 & 8.86 & 65.26 & 532.82 & -0.10 \\
\hline & 18.4 & 10.2 & 2.8 & 31.4 & & & & & & & \\
\hline & 58.8 & 32.5 & 8.8 & & & & & & & & \\
\hline
\end{tabular}


Table 2 continued

\begin{tabular}{|c|c|c|c|c|c|c|c|c|c|c|c|}
\hline Sample no. & $\mathrm{Cl}^{-}$ & $\mathrm{SO}_{4}^{-}$ & $\mathrm{HCO}_{3}{ }^{-}$ & $\begin{array}{l}\text { Sum } \\
\text { Ani. }\end{array}$ & $\mathrm{EC} \mu \mathrm{mhos} / \mathrm{cm}$ & PH & TDS (mg/l) & SAR (epm) & $\mathrm{Na} \%$ (epm) & Hardness (ppm) & Error \\
\hline \multirow[t]{3}{*}{ Q11 } & 1389.6 & 1434.4 & 260.0 & & 7151 & 7.00 & 4603 & 9.84 & 54.13 & 1709.91 & 1.25 \\
\hline & 39.2 & 29.8 & 4.3 & 73.3 & & & & & & & \\
\hline & 53.5 & 40.7 & 5.8 & & & & & & & & \\
\hline \multirow[t]{3}{*}{ Q12 } & 1268.0 & 1410.7 & 318.0 & & 6944 & 6.80 & 4471 & 12.21 & 62.49 & 1320.23 & 0.49 \\
\hline & 35.8 & 29.3 & 5.2 & 70.3 & & & & & & & \\
\hline & 50.9 & 41.7 & 7.4 & & & & & & & & \\
\hline \multirow[t]{3}{*}{ Q13 } & 1290.0 & 1599.0 & 384.0 & & 7600 & 7.07 & 4891 & 14.18 & 66.36 & 1266.34 & 0.07 \\
\hline & 36.4 & 33.3 & 6.3 & 75.9 & & & & & & & \\
\hline & 47.9 & 43.8 & 8.3 & & & & & & & & \\
\hline \multirow[t]{3}{*}{ Q14 } & 1461.0 & 1601.0 & 578.0 & & 8357 & 7.06 & 5375 & 12.64 & 60.63 & 1650.33 & 0.40 \\
\hline & 41.2 & 33.3 & 9.5 & 84.0 & & & & & & & \\
\hline & 49.1 & 39.7 & 11.3 & & & & & & & & \\
\hline \multirow[t]{3}{*}{ Q15 } & 1355.0 & 1781.0 & 572.0 & & 8460 & 6.90 & 5442 & 12.25 & 59.58 & 1695.67 & 0.03 \\
\hline & 38.2 & 37.0 & 9.4 & 84.6 & & & & & & & \\
\hline & 45.1 & 43.8 & 11.1 & & & & & & & & \\
\hline \multirow[t]{3}{*}{ Q16 } & 1348.0 & 1776.0 & 537.0 & & 8354 & 6.90 & 5374 & 12.26 & 59.81 & 1665.45 & -0.07 \\
\hline & 38.0 & 36.9 & 8.8 & 83.8 & & & & & & & \\
\hline & 45.4 & 44.1 & 10.5 & & & & & & & & \\
\hline \multirow[t]{3}{*}{ Q17 } & 2110.0 & 1295.0 & 138.0 & & 8430 & 7.00 & 5423 & 11.30 & 55.67 & 1994.18 & 1.08 \\
\hline & 59.5 & 26.9 & 2.3 & 88.7 & & & & & & & \\
\hline & 67.1 & 30.4 & 2.6 & & & & & & & & \\
\hline \multirow[t]{3}{*}{ Q18 } & 2142.0 & 1325.6 & 142.0 & & 8561 & 7.00 & 5506 & 11.97 & 57.43 & 1932.69 & 0.74 \\
\hline & 60.4 & 27.6 & 2.3 & 90.3 & & & & & & & \\
\hline & 66.9 & 30.5 & 2.6 & & & & & & & & \\
\hline \multirow[t]{3}{*}{ Q19 } & 1692.0 & 1531.5 & 96.0 & & 7748 & 7.00 & 4986 & 10.38 & 54.63 & 1828.19 & 0.05 \\
\hline & 47.7 & 31.9 & 1.6 & 81.1 & & & & & & & \\
\hline & 58.8 & 39.3 & 1.9 & & & & & & & & \\
\hline \multirow[t]{3}{*}{ Q20 } & 1719.1 & 1464.0 & 89.0 & & 7643 & 7.00 & 4918 & 10.47 & 55.22 & 1773.33 & -0.32 \\
\hline & 48.5 & 30.5 & 1.5 & 80.4 & & & & & & & \\
\hline & 60.3 & 37.9 & 1.8 & & & & & & & & \\
\hline
\end{tabular}

than unity, which reflects a meteoric water origin. But the excess of chloride than sodium in the other samples are attributed to the chemical local reaction due to enrichment of sodium or local ionic exchange reaction. For the NSAS, all the groundwater samples $(100 \%)$ have less than unity reflecting the marine water origin of groundwater.

The $\mathrm{rSO}_{4}{ }^{-} / \mathrm{rCl}^{-}$ratio is useful as a guide for detecting any excess in sulfate content in the groundwater due to dissolution of calcium sulfate or precipitation of calcium carbonate. This ratio indicates the dissolution of sulfate minerals, i.e., gypsum and anhydrite. The value of this ratio in the majority of water samples collected from the QAS $(95 \%)$ is less than unity. This reflects a limited solution of the local terrestrial source of sulfate, such as gypsum and anhydrite minerals in groundwater. The rest of the samples $(5 \%)$ have $\mathrm{rSO}_{4}{ }^{-} / \mathrm{rCl}^{-}$more than unity. The value of this ratio in all the water samples from the
NSAS (100\%) is less than unity. This reflects a limited solution of the local terrestrial source of sulfate minerals in groundwater.

The $\mathrm{rCa}^{++} / \mathrm{rMg}^{++}$parameter is important for tracing seawater contamination. High values may indicate a source of $\mathrm{Ca}$ as evaporates and active base exchange processes. $\mathrm{Ca} / \mathrm{Mg}$ value in all wells from the QAS and the NSAS are more than one (except sample no. 10), where there is an increase in $\mathrm{Ca}$ ion content, which may result from the precipitation of calcium carbonate or calcium sulfate.

Regarding the $\left(\mathrm{rCl}^{-} \mathrm{rNa}^{+} / \mathrm{rCl}^{-}\right)$, the negative values for this index indicate an active cation exchange process. This ratio in groundwater samples collected from the QAS (75 \%) has negative value. This reflects a reaction between the groundwater and the aquifer sediments rich in clay lenses. The rest of the samples of the QAS (25\%) and all of the NSAS have positive values. They contain an 
Table 3 Chemical analysis data of the collected water samples from NSAS in the study area

\begin{tabular}{|c|c|c|c|c|c|c|c|c|c|c|}
\hline \multirow[t]{2}{*}{ Sample no. } & & \multicolumn{3}{|c|}{ Location } & \multirow[t]{2}{*}{ Units } & \multirow[t]{2}{*}{$\mathrm{Ca}^{+}$} & \multirow[t]{2}{*}{$\mathrm{Mg}^{2+}$} & \multirow[t]{2}{*}{$\mathrm{Na}^{+}$} & \multirow[t]{2}{*}{$\mathrm{K}^{+}$} & \multirow{2}{*}{$\begin{array}{l}\text { Sum } \\
\text { Cat. }\end{array}$} \\
\hline & & Deg. & Min. & Sec. & & & & & & \\
\hline \multirow[t]{3}{*}{ N1 } & $\mathrm{N}$ & 26 & 47 & 22.9 & $\mathrm{mg} / \mathrm{l}$ & 115.0 & 49.0 & 411.0 & 12.1 & \\
\hline & & & & & meq/l & 5.7 & 4.0 & 17.9 & 0.3 & 28.0 \\
\hline & $\mathrm{E}$ & 32 & 47 & 18 & e $\%$ & 20.5 & 14.4 & 64.0 & 1.1 & \\
\hline \multirow[t]{3}{*}{$\mathrm{N} 2$} & $\mathrm{~N}$ & 26 & 41 & 56.8 & $\mathrm{mg} / \mathrm{l}$ & 110.0 & 57.4 & 399.0 & 9.7 & \\
\hline & & & & & meq/l & 5.5 & 4.7 & 17.4 & 0.2 & 27.8 \\
\hline & $\mathrm{E}$ & 32 & 47 & 56.1 & e $\%$ & 19.7 & 17.0 & 62.4 & 0.9 & \\
\hline \multirow[t]{3}{*}{ N3 } & $\mathrm{N}$ & 26 & 31 & 40.3 & $\mathrm{mg} / \mathrm{l}$ & 98.8 & 57.7 & 390.0 & 8.0 & \\
\hline & & & & & $\mathrm{meq} / \mathrm{l}$ & 4.9 & 4.7 & 17.0 & 0.2 & 26.8 \\
\hline & $\mathrm{E}$ & 32 & 46 & 48.5 & e $\%$ & 18.4 & 17.7 & 63.2 & 0.8 & \\
\hline \multirow[t]{3}{*}{ N4 } & $\mathrm{N}$ & 26 & 27 & 29.2 & $\mathrm{mg} / \mathrm{l}$ & 92.2 & 52.4 & 345.2 & 8.5 & \\
\hline & & & & & meq/l & 4.6 & 4.3 & 15.0 & 0.2 & 24.1 \\
\hline & $\mathrm{E}$ & 32 & 47 & 52.5 & e $\%$ & 19.1 & 17.9 & 62.2 & 0.9 & \\
\hline \multirow[t]{3}{*}{ N5 } & $\mathrm{N}$ & 26 & 26 & 54.7 & $\mathrm{mg} / \mathrm{l}$ & 90.1 & 48.2 & 370.9 & 5.6 & \\
\hline & & & & & meq/l & 4.5 & 4.0 & 16.1 & 0.1 & 24.7 \\
\hline & $\mathrm{E}$ & 32 & 46 & 11 & e $\%$ & 18.2 & 16.0 & 65.2 & 0.6 & \\
\hline \multirow[t]{3}{*}{ N6 } & $\mathrm{N}$ & 26 & 16 & 0.2 & $\mathrm{mg} / \mathrm{l}$ & 88.0 & 46.0 & 360.0 & 5.4 & \\
\hline & & & & & $\mathrm{meq} / 1$ & 4.4 & 3.8 & 15.7 & 0.1 & 24.0 \\
\hline & E & 32 & 47 & 8.3 & e $\%$ & 18.3 & 15.8 & 65.3 & 0.6 & \\
\hline
\end{tabular}

\begin{tabular}{|c|c|c|c|c|c|c|c|c|c|c|c|}
\hline Sample no. & $\mathrm{Cl}^{-}$ & $\mathrm{SO}_{4}^{-}$ & $\mathrm{HCO}_{3}{ }^{-}$ & $\begin{array}{l}\text { Sum } \\
\text { Ani. }\end{array}$ & $\begin{array}{l}\mathrm{EC} \\
\mu \mathrm{mhos} / \mathrm{cm}\end{array}$ & $\mathrm{PH}$ & TDS (mg/l) & SAR (epm) & $\mathrm{Na} \%$ (epm) & Hardness (ppm) & Error \\
\hline \multirow[t]{3}{*}{ N1 } & 649.0 & 335.0 & 144.0 & & 2685 & 6.80 & 1715 & 8.09 & 64 & 488 & 0.58 \\
\hline & 18.3 & 7.0 & 2.4 & 27.6 & & & & & & & \\
\hline & 66.2 & 25.2 & 8.5 & & & & & & & & \\
\hline \multirow[t]{3}{*}{ N2 } & 647.6 & 331.0 & 142.0 & & 2657 & 7.00 & 1697 & 7.68 & 62 & 510 & 0.61 \\
\hline & 18.3 & 6.9 & 2.3 & 27.5 & & & & & & & \\
\hline & 66.5 & 25.1 & 8.5 & & & & & & & & \\
\hline \multirow[t]{3}{*}{ N3 } & 635.5 & 337.5 & 130.0 & & 2597 & 6.80 & 1657 & 7.71 & 63 & 484 & -0.43 \\
\hline & 17.9 & 7.0 & 2.1 & 27.1 & & & & & & & \\
\hline & 66.2 & 25.9 & 7.9 & & & & & & & & \\
\hline \multirow[t]{3}{*}{ N4 } & 566.4 & 313.9 & 130.6 & & 2372 & 7.00 & 1509 & 7.11 & 62 & 445 & -1.02 \\
\hline & 16.0 & 6.5 & 2.1 & 24.6 & & & & & & & \\
\hline & 64.8 & 26.5 & 8.7 & & & & & & & & \\
\hline \multirow[t]{3}{*}{ N5 } & 589.8 & 237.2 & 168.1 & & 2373 & 7.00 & 1510 & 7.85 & 65 & 423 & 0.85 \\
\hline & 16.6 & 4.9 & 2.8 & 24.3 & & & & & & & \\
\hline & 68.4 & 20.3 & 11.3 & & & & & & & & \\
\hline \multirow[t]{3}{*}{ N6 } & 580.0 & 244.1 & 172.0 & & 2351 & 7.68 & 1496 & 7.75 & 65 & 409 & -0.59 \\
\hline & 16.4 & 5.1 & 2.8 & 24.3 & & & & & & & \\
\hline & 67.4 & 20.9 & 11.6 & & & & & & & & \\
\hline
\end{tabular}

abundance of $\mathrm{NaCl}$ salt and indicate low to moderately active ion exchange.

\section{Groundwater genetic classification}

The groundwater in the investigated area was classified using Sulin's graph (1962) to detect its genesis. The representation of groundwater samples for the QAS in Sulin's graph (Fig. 11a) indicated that the majority of wells in the study area were of meteoric origin (15 wells) and all of them had $\mathrm{Na}_{2} \mathrm{SO}_{4}$ content, while five wells were classified of marine origin and had $\mathrm{MgCl}_{2}$ content. This may indicate mixing of the meteoric and marine origin in the lower mixed part between the QAS and NSAS. On the 


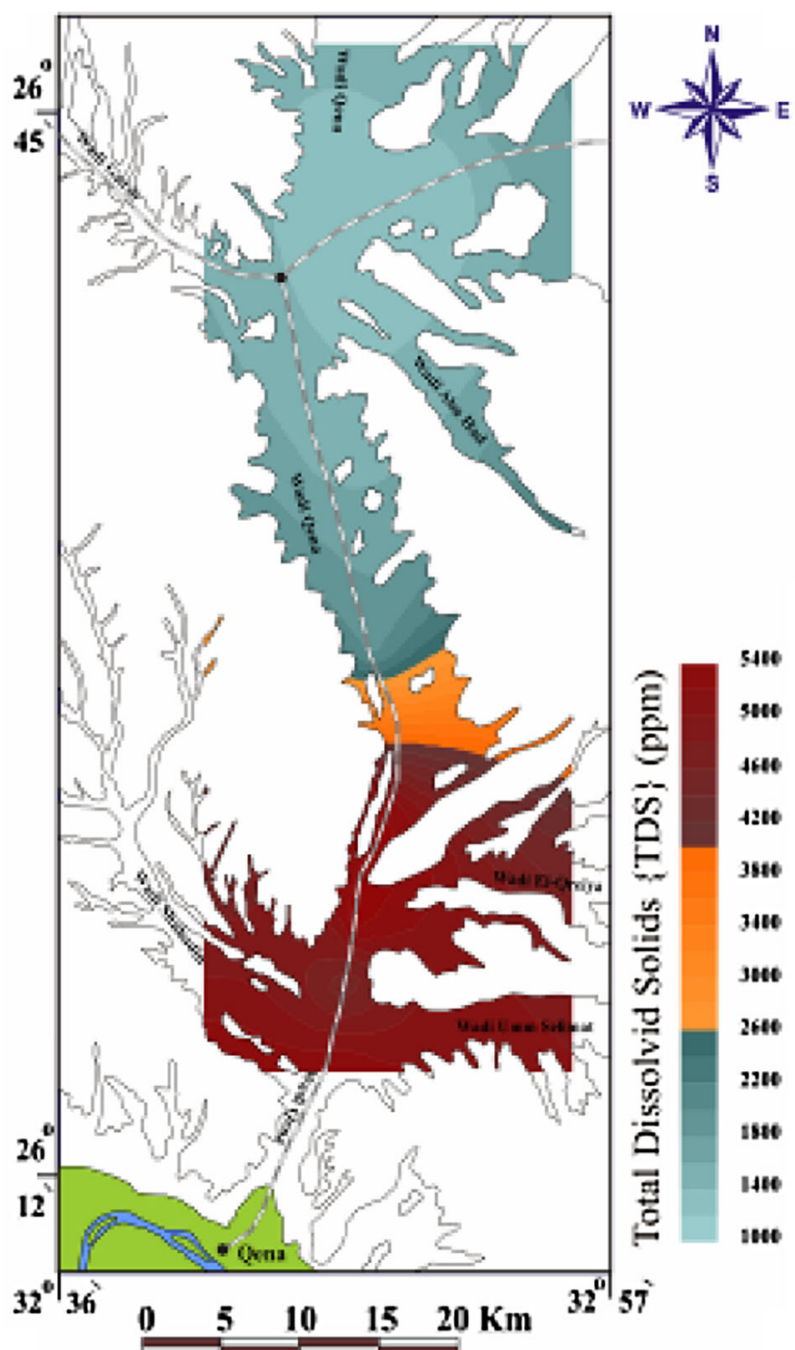

Fig. 5 Iso-salinity distribution of the groundwater of QAS in the study area

other hand, all the samples of the NSAS (Fig. 11b) are located in the $\mathrm{MgCl}$, indicating the marine origin of groundwater.

\section{Evaluation of groundwater for different purposes}

\section{Municipal purpose}

The suitability of groundwater form the QAS and NSAS for drinking purposes were evaluated based on the Egyptian drinking water quality standards (ARE 2007). A comparison between the allowable limits for the TDS, cations and anions is given in Table 5. According to the table, the water is not suitable for drinking purposes, as all the samples contain concentration of one element or other above the allowable limits for drinking purposes.

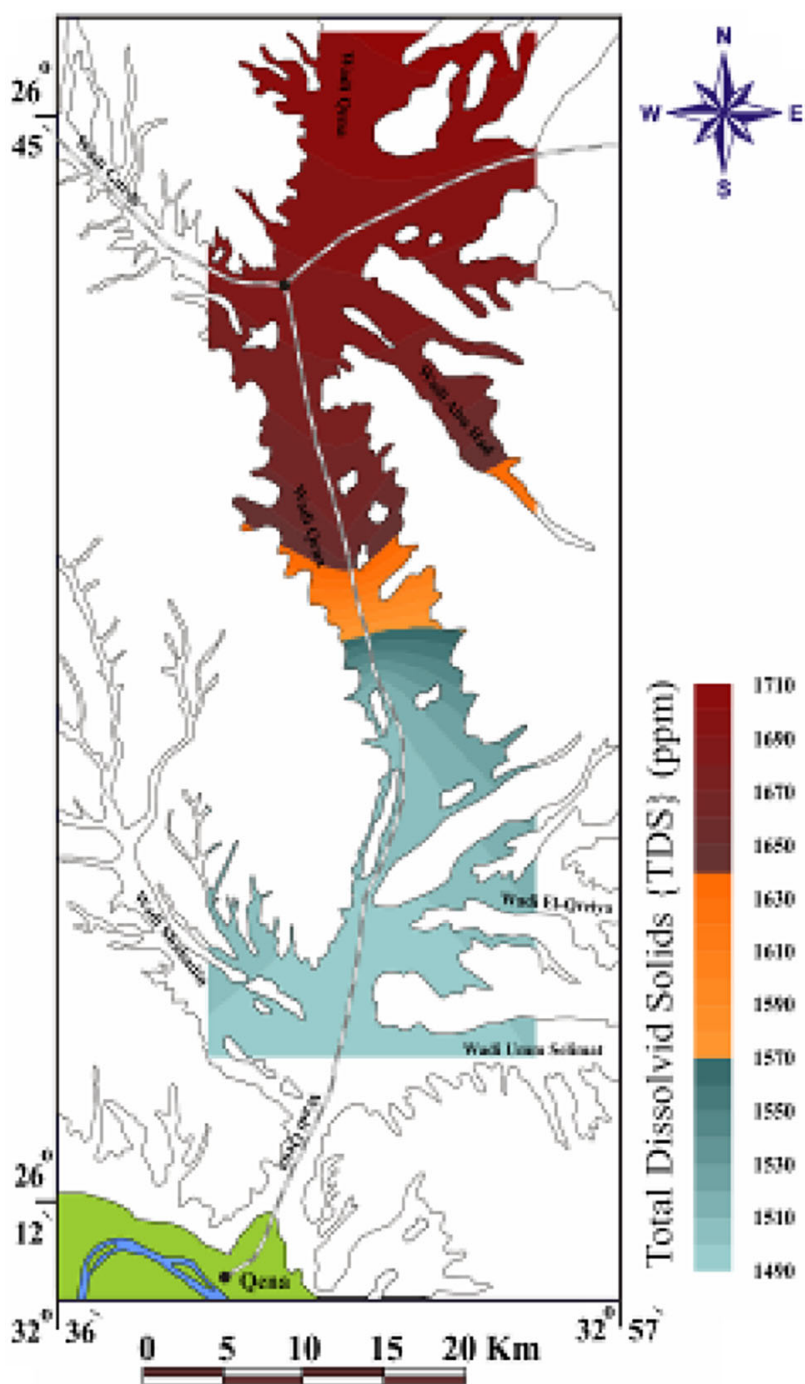

Fig. 6 Iso-salinity distribution of the groundwater of NSAS in the study area

The total hardness plays a very important role in domestic water, whereas the total hardness should be below 120 epm (Hem 1970). The most controlling factor in laundry water is the total hardness concentration $(\mathrm{TH})$, which is determined by the relation between $\mathrm{Ca}^{2+}+\mathrm{Mg}^{2+}$ (Hem 1970). The total hardness of the groundwater in the study area is more than 120 epm (hard water), as shown in Tables 2 and 3. Therefore, water is unsuitable for drinking water and domestic purposes.

\section{Irrigation purposes}

Four most common factors are considered herein for the evaluation of the usefulness of water for irrigation purposes in the study area. They are the total dissolved salts (TDS), sodium adsorption ratio (SAR), residual sodium carbonates (RSC) and chloride content $(\mathrm{Cl})$. 


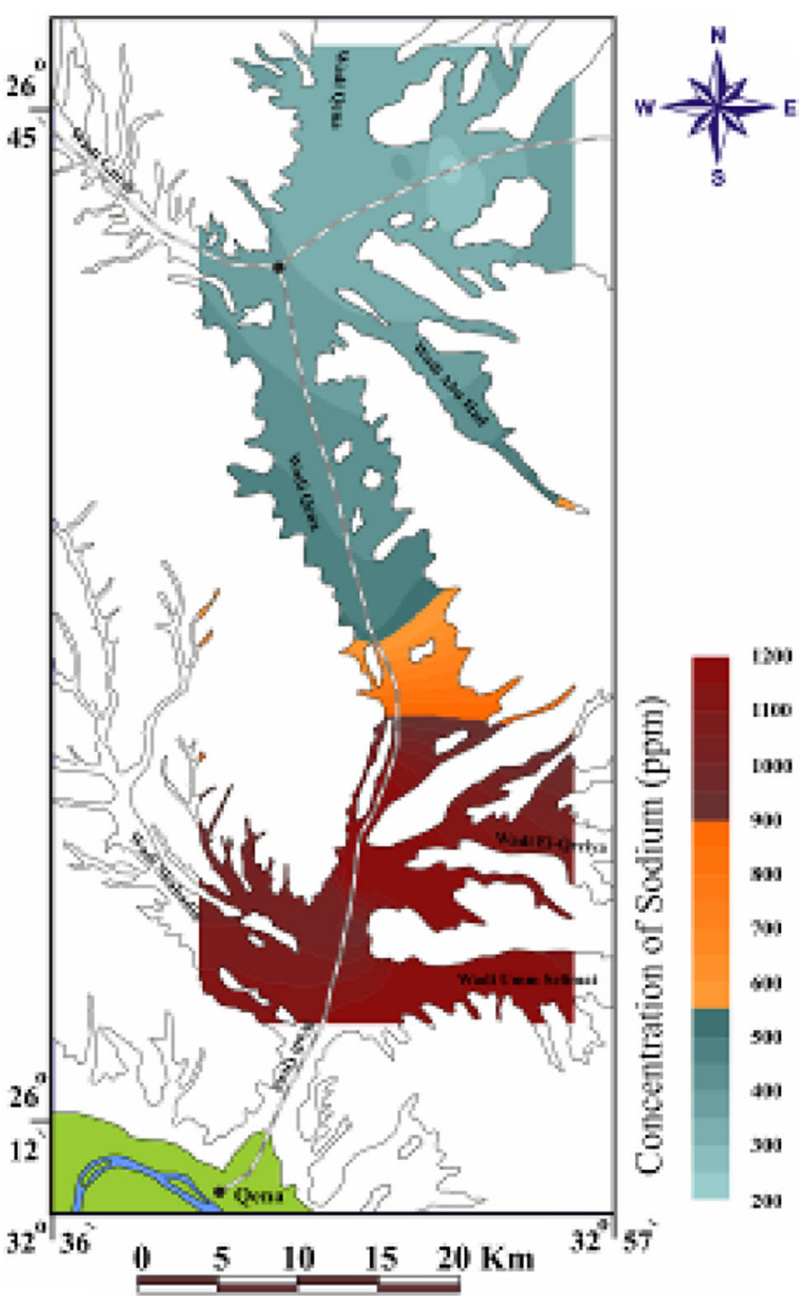

Fig. 7 Iso- sodium map of QAS in the study area

The concentration of the total dissolved salts (TDS) is considered to be an indication to the degree of salinity problems that might be anticipated when the groundwater is used for irrigation purposes. The US Salinity Laboratory classification (1954) differentiates the water sources into five categories according to salinity and therefore electric conductivity (E.C). Based on this diagram, the studied groundwater samples are located in the categories $\mathrm{C}_{3}, \mathrm{C}_{4}$ and $\mathrm{C}_{5}$, where $\mathrm{C}_{3}$ (sample no. Q4, Q5, Q6 and Q7) is suitable to some extent, so special management for salinity control may be required and plants with good salt tolerance should be selected. The water of other category $\left(\mathrm{C}_{4}\right)$, samples nos. Q1, Q2, Q3, Q8, Q9, Q10, N1, N2, N3, N4, $\mathrm{N} 5$ and N6, are not suitable for irrigation under ordinary conditions, but may be used occasionally under very special circumstances. The soil must be permeable and water management for salinity control and leaching is necessary to remove the excess salts. Salt-tolerant crops must be chosen in this case. The excessive saline water $\left(\mathrm{C}_{5}\right)$ is represented by the well nos. Q11,Q12, Q13, Q14, Q15,

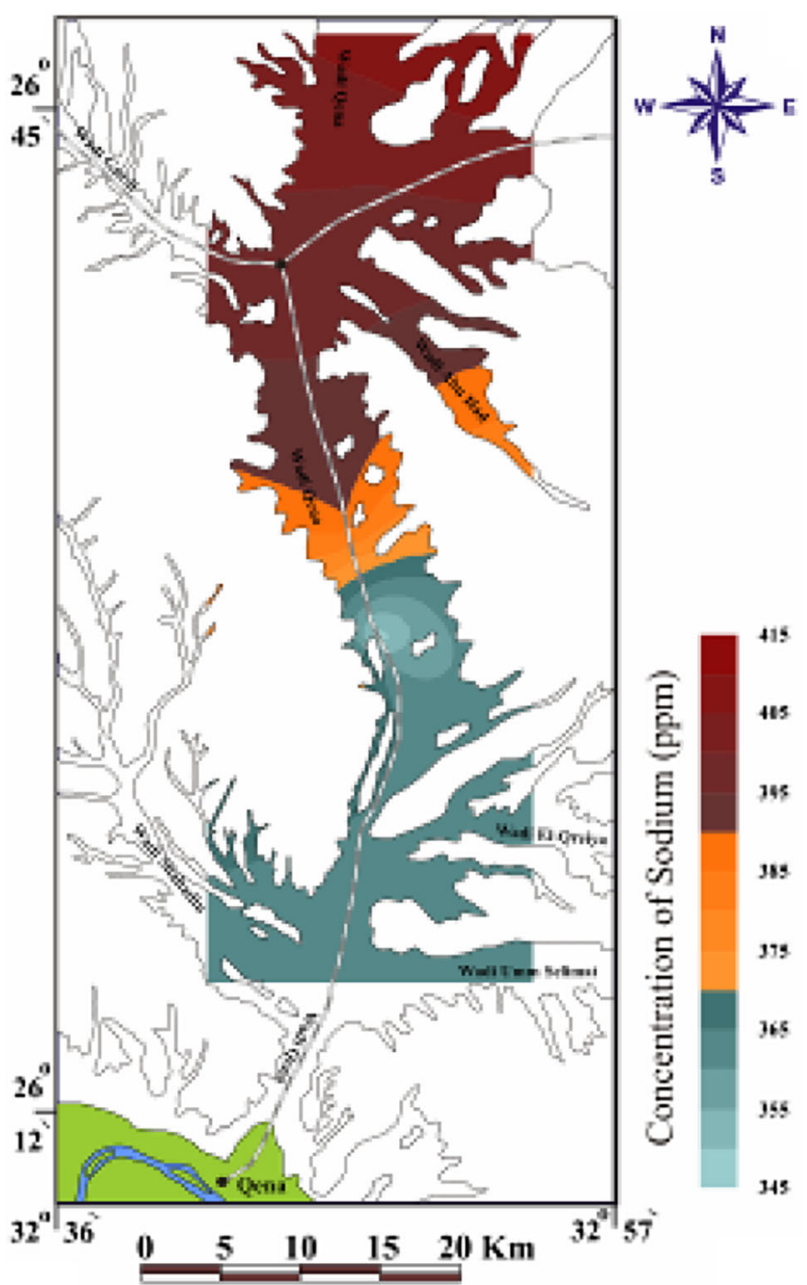

Fig. 8 Iso- sodium map of NSAS in the study area

Q16, Q17, Q18,Q19 and Q20. This category is generally unsuitable for irrigation; plants of high salt tolerance must be chosen and frequent leaching must be carried out to prevent serious salinity.

Wilcox (1948) suggested a useful nomogram for water suitability for irrigation (the nomogram was modified later by US Department of Irrigation (1954), is that based on the sodium adsorption ratio (SAR) the water is classified into four types. From the plots of the analyzed water samples, they are considered to be within two main categories (Figs. 12,13). The first category consists of water of very high salinity and medium SAR (C4-S2), which is represented by nine groundwater samples (well nos. Q1, Q2, Q3, N1, N2, N3, N4, N5 and N6). Special management should be followed to reduce salinity with selection of salt-tolerant crops on soil of good permeability with special leaching. The second main category consists of water of very high salinity and high SAR (C4S3) where three samples are located (sample nos. Q8, Q9 and Q10). This water is not suitable for irrigation under ordinary conditions, but may 


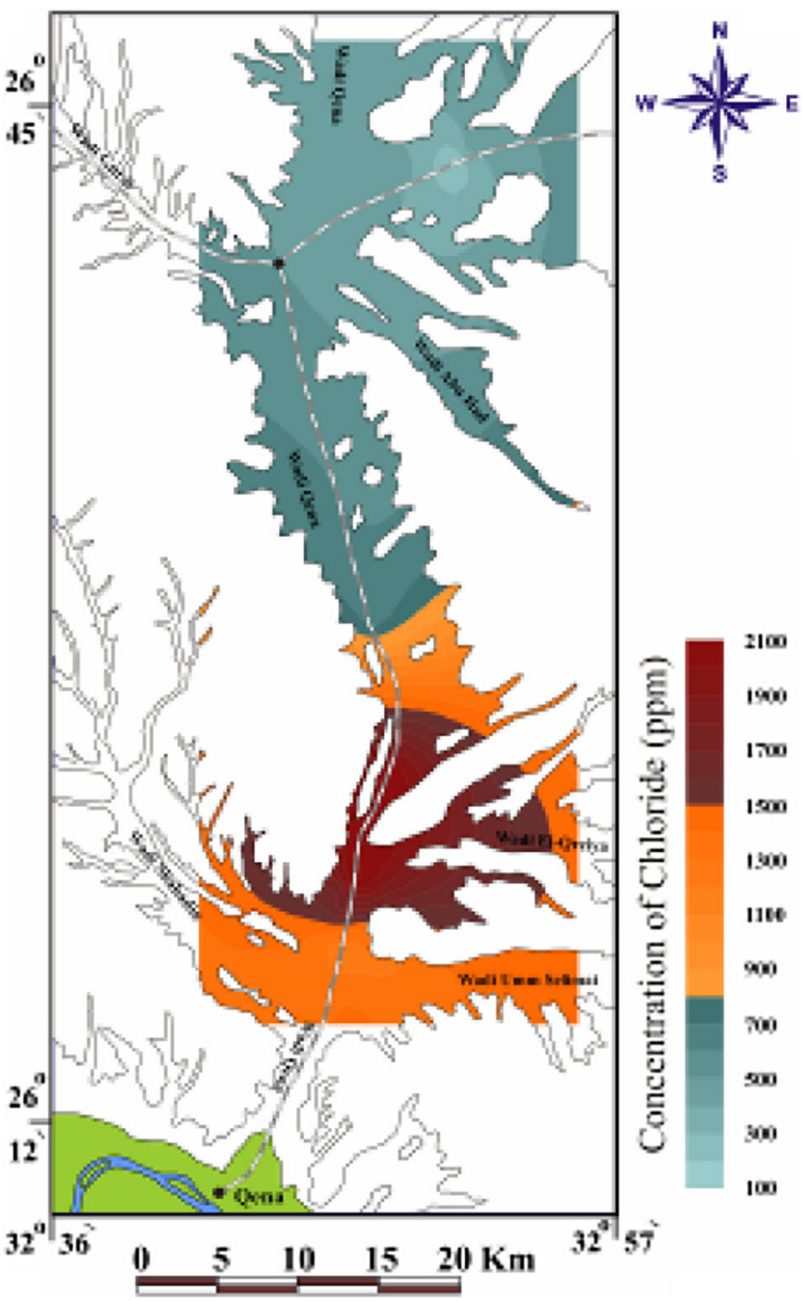

Fig. 9 Iso-chloride zonation map of QAS in the study area

be used occasionally under very special circumstances. The soil must be permeable, drainage must be adequate, irrigation must be applied in excess to provide considerable leaching and highly salt-tolerant crops should be selected. The rest of the samples are located outside the nomogram where they contain high amounts and SAR and TDS. In conclusion, the results indicated that the drainage condition of the soil in the area should be improved to increase the crop productivity in the area.

Eaton (1950) had classified the water for irrigation considering its bicarbonate content. He introduced the residual sodium carbonate (RSC) value expressed by the relation between carbonate, bicarbonate, calcium and magnesium concentrations in water (in meq/l). The RSC is used to distinguish between the different water classes for irrigation purposes. Moreover, the high concentration of bicarbonate ions in the irrigation water leads to its toxicity and affects the mineral nutrition of plants. The RSC values range from -2.2 to $-37.62 \mathrm{epm} / \mathrm{l}$ with an average of -17.38 for the QAS, while it ranges from -5.35 to -7.88

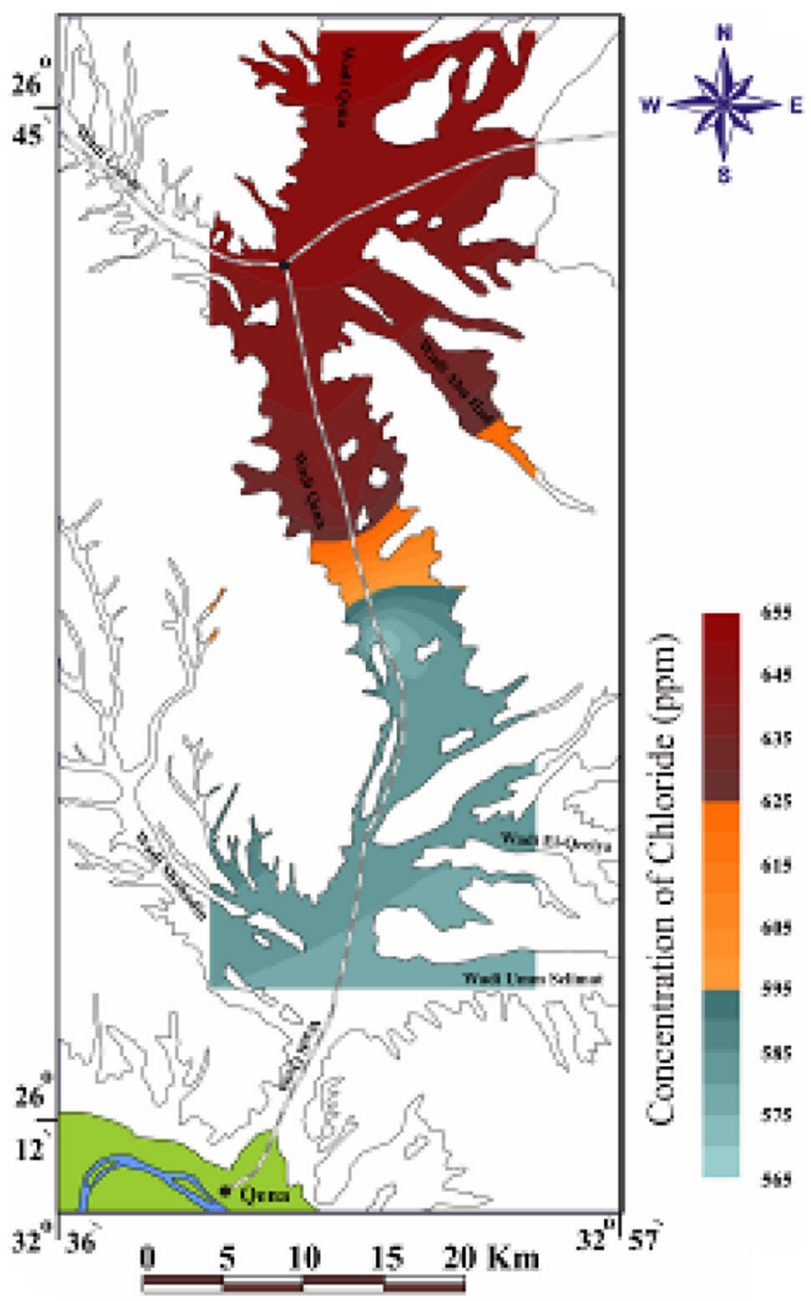

Fig. 10 Iso-chloride zonation map of NSAS in the study area

with an average of $-6.77 \mathrm{epm}$ for NSAS. This is an indication of the fact that water is of very good quality, non hazard and suitable for irrigation purposes (as the RSC is $<1.25 \mathrm{epm})$.

Taylor and Oza (1954) classified the groundwater for irrigation according to chloride content. According to their classification, the studied groundwater sample of 1 well (no. Q4) is considered to be of good quality and suitable for all tolerant plants and 4 wells are considered to be of fair quality and suitable for all tolerant plants, while 11 wells are undesirable for irrigation except for salt-tolerant plants. On the other hand, ten wells were highly undesirable for irrigation, except for highly salt-tolerant plants (Table 6).

\section{Livestock and poultry purposes}

High salinity in water can cause physiological changes or even death of livestock. The suitability of water for livestock and poultry depending on salinity values is studied based on FAO (1984) guidelines. The results showed that 
Table 4 Maximum, minimum and average hydrochemical parameters of QAS and NSAS

Fig. 11 Sulin's graph for genetic classification of groundwater in QAS (a) and NSAS (b)

\begin{tabular}{lllllc}
\hline Aquifer samples & Ratio & $\mathrm{rNa}^{+} / \mathrm{rCl}^{-}$ & $\mathrm{rSO}_{4}{ }^{2-} / \mathrm{rCl}^{-}$ & $\mathrm{rCa}^{2+} / \mathrm{rMg}^{2+}$ & $\left\{\mathrm{rCl}^{2-} \mathrm{rNa}^{+}\right\} / \mathrm{rCl}^{-}$ \\
\hline QAS & Max & 0.99 & 2 & 5.01 & 0.17 \\
& Min & 0.1 & 0.4 & 0.77 & -0.73 \\
\multirow{3}{*}{ NSAS } & Average & 0.19 & 0.71 & 2.22 & -0.14 \\
& Max & 0.97 & 0.41 & 1.42 & 0.06 \\
& Min & 0.94 & 0.3 & 1.04 & 0.03 \\
& Average & 0.96 & 0.37 & 1.20 & 0.04 \\
\hline
\end{tabular}
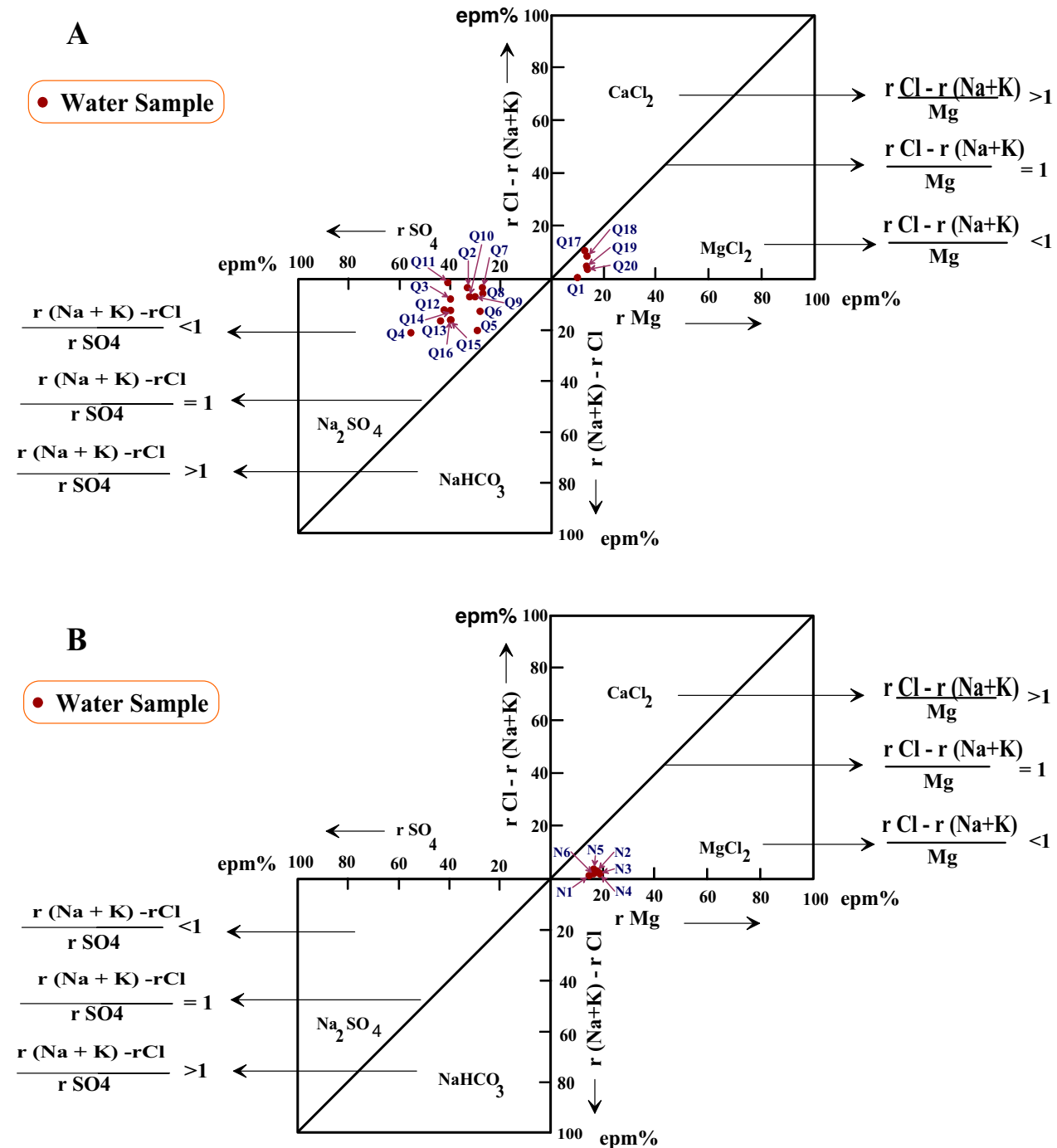

16 groundwater samples (10 of QAS and 6 of NSAS) have salinity ranging from 1000 to $2999 \mathrm{mg} / \mathrm{L}$. These are very satisfactory for all classes of livestock and poultry, but may cause temporary and mild diarrhea in livestock not accustomed to such water, or watery dropping in poultry. Five groundwater samples from the QAS had relatively high salinity content (3000-4999 ppm). The use of this type may cause temporary diarrhea or may be refused at first by animals not accustomed to it. Also, it often causes watery feces, increased mortality and decreased growth. The resuts showed that the salinity contents of five samples collected from the QAS are of high salinity content (5000-6999 ppm) and have a considerable risk if this water is used for the dairy beef cattle, for sheep, swine and horses. 
Table 5 Water quality for drinking purposes in the QAS and NSAS

\begin{tabular}{|c|c|c|c|c|c|c|c|}
\hline Element & $\mathrm{pH}$ & $\mathrm{Ca}$ & $\mathrm{Mg}$ & $\mathrm{Na}$ & $\mathrm{Cl}$ & $\mathrm{SO}_{4}$ & TDS \\
\hline Allowable limit (ppm) & $6.5-8.5$ & 350 & 150 & 200 & 250 & 250 & 1000 \\
\hline \multicolumn{8}{|l|}{$Q A S$} \\
\hline Suitable & All samples & Q1: Q10 & Q1: Q10 Q12, Q13 & Q4 & Q4 & Non & Non \\
\hline$\%$ & 100 & 50 & 60 & 5 & 5 & 0 & 0 \\
\hline Unsuitable & nom & Q11:Q20 & Q11,Q14:20 & The rest & The rest & All samples & All samples \\
\hline$\%$ & 0 & 50 & 40 & 95 & 95 & 100 & 100 \\
\hline \multicolumn{8}{|l|}{ NSAS } \\
\hline Suitable & All samples & All samples & All samples & Non & Non & Non & Non \\
\hline$\%$ & 100 & 100 & 100 & 0 & 0 & 0 & 0 \\
\hline Unsuitable & Non & Non & Non & All & All & All & All \\
\hline$\%$ & 0 & 0 & 0 & 100 & 100 & 100 & 100 \\
\hline
\end{tabular}

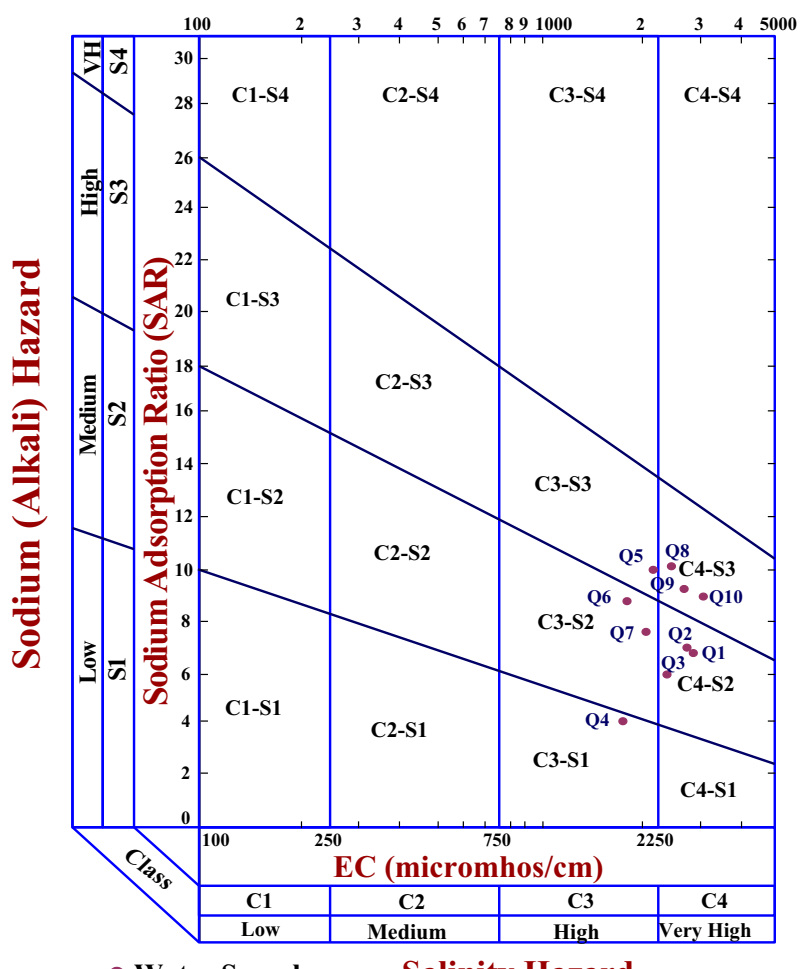

- Water Sample Salinity Hazard

Fig. 12 Classification of groundwater for irrigation of QAS (U.S. Salinity Laboratory Staff 1954)

\section{Chemical equilibrium and saturation index (SI)}

The saturation indices are used to express the water tendency toward precipitation or dissolution. The degree of water saturation with respect to a mineral is given by; $\mathrm{SI}=\log \left(K_{\mathrm{IAP}} / K_{\mathrm{sp}}\right)$, where $K_{\mathrm{IAP}}$ is the ionic activity product, $K_{\mathrm{sp}}$ is the solubility product and SI is the saturation index of the concerned mineral. When SI is equal to zero, the water is at equilibrium or saturated with the mineral

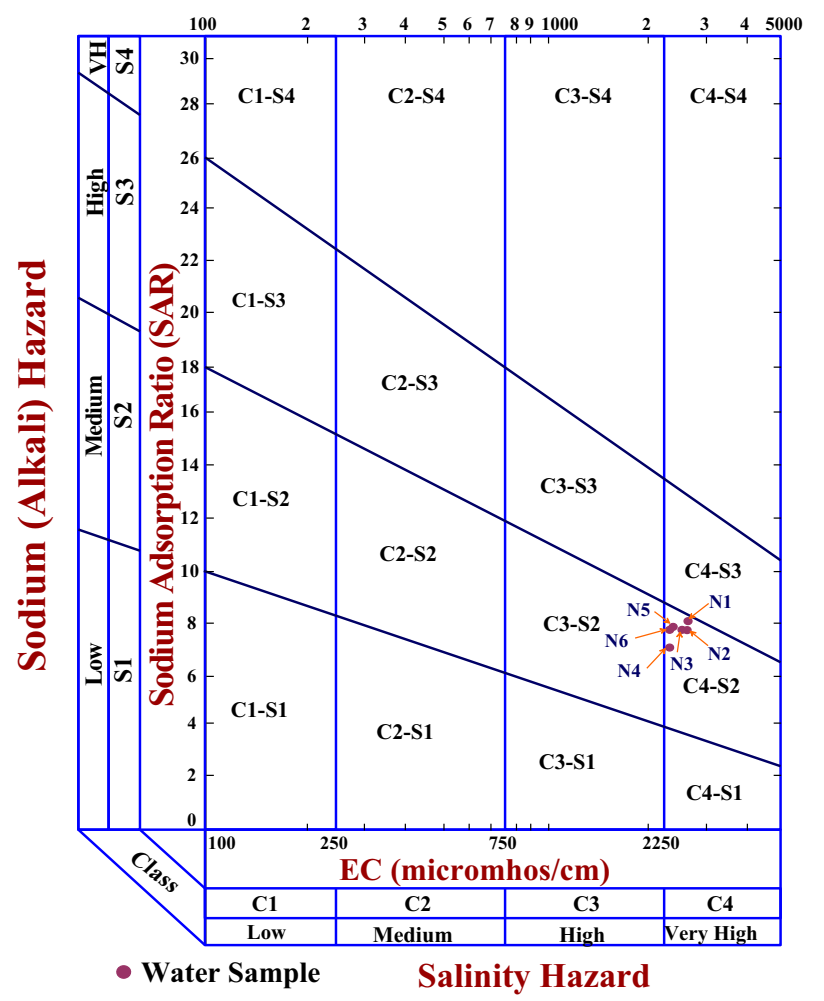

Fig. 13 Classification of groundwater for irrigation of NSAS (U.S. Salinity Laboratory Staff 1954)

phase; if SI value is less than zero (negative value), this indicates that water is undersaturated and that the mineral phase tends to dissolve, whereas SI value over zero (positive value) indicates the supersaturation of water and that the mineral phase tends to precipitate. The saturation indices (SI) of the major mineral phases in the different aquifers in the investigated groundwater samples were calculated using the software package (NETPATH-WIN, El kadi et al. 2010). The obtained results (Fig. 14) reflect that: 
Table 6 Suitability of water for irrigation in the study area based on the chloride content (Taylor 1954)

\begin{tabular}{llll}
\hline Class & $\mathrm{Cl}(\mathrm{ppm})$ & Quality & Studied wells \\
\hline I & $<200$ & Good & Q4 \\
II & $200-500$ & Fair & Q3, Q5, Q6, and Q7 \\
III & $500-1000$ & Undesirable & Q1, Q2, Q8, Q9, Q10, N1, N2, N3, N4, N5 and N6 \\
IV & $>1000$ & Highly undesirable & Q11, Q12, Q13, Q14, Q15, Q16, Q17, Q18, Q19 and Q20 \\
\hline
\end{tabular}

Fig. 14 Saturation indices with respect to minerals in the QAS and NSAS samples
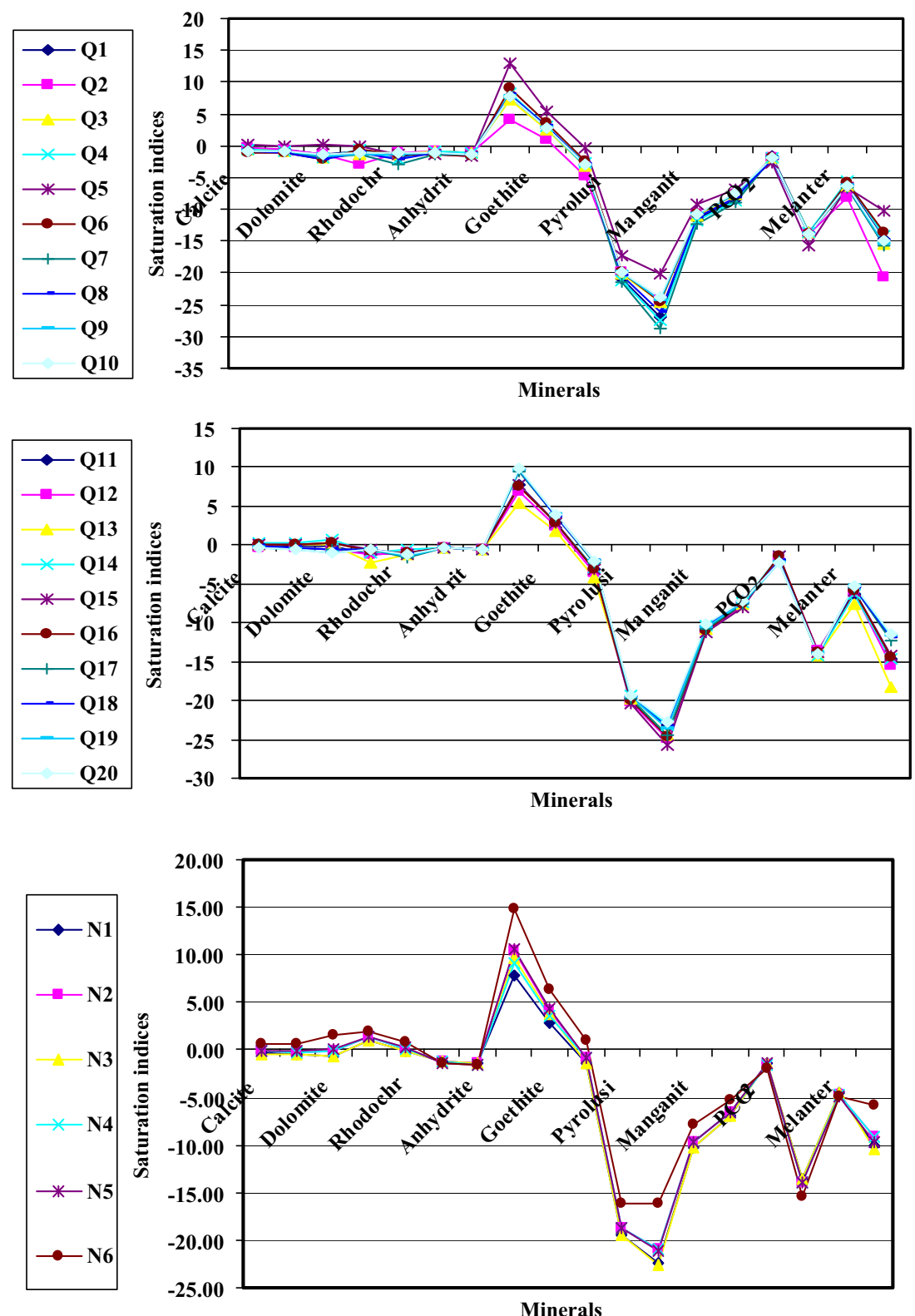

1. The groundwater is supersaturated with respect to iron mineral phases (hematite, goethite) where the SI is above zero. Hematite, goethite and siderite reflect the sensitivity of iron to oxidation even in low concentrations.

2. The groundwater in the two aquifers is undersaturated with respect to the main carbonate minerals (calcite, aragonite, dolomite, siderite and rhodochrosite) and also undersaturated regarding sulfate minerals (gypsum and Anhydrite). This is clear where the $\mathrm{pH}$ values reflect a slightly alkaline character. The main source of carbonates in this aquifer is the atmosphere, where $\mathrm{CO}_{2}$ reacts with the rainwater to form the bicarbonate ions in addition to leaching of carbonate materials. 


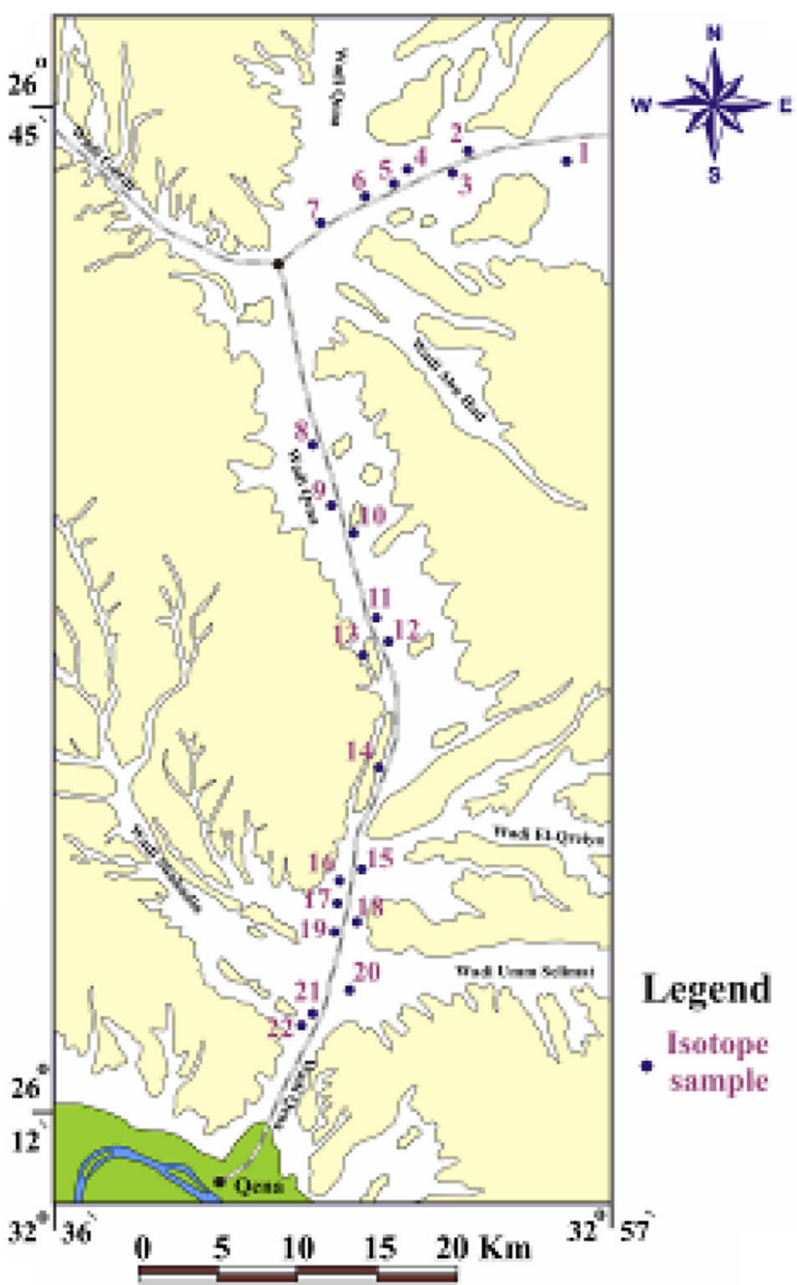

Fig. 15 Location map of groundwater samples for isotope analysis

\section{Isotope analysis and age dating}

The usefulness of stable isotopes as tracer in hydrology has been demonstrated since the emergence of the field of isotope geochemistry in the 1950s. The earliest applications of isotopes as tracers were in the identification of clear-cut isotopic relationships between ${ }^{18} \mathrm{O}$ and ${ }^{2} \mathrm{H}$ in worldwide waters, arising due to isotopic fractionation occurring in the hydrological cycles (Craig 1961).

In the study area, 22 water samples were collected in April 2013 (Fig. 15) and subjected to environmental isotope analysis. The result is shown in Table 7.

Hamza et al. (2009) presented a scheme of the application of the two-component mixing model with the correction of $\delta^{18} \mathrm{O}$ values for evaporative isotope enrichment (Fig. 16. The raw and corrected $\delta^{18} \mathrm{O}$ values of the Nile water are represented by the points 1 and 2, respectively. The determined $\delta^{18} \mathrm{O}$ value of the sample and the corrected ones using a slope of 5.8 are represented by the points 3 and 4 . The end member value of the Nubian sandstone water is found at point 5 .
The water samples from wells in the groundwater samples yielded $\delta^{18} \mathrm{O}$ and $\delta^{2} \mathrm{H}$ values ranging from -7.07 to $-2.64 \%$ and from -52.33 to $-23.50 \%$, respectively (Table 7). The mean values for all data are -4.99 and $-35.62 \%$ for $\delta^{18} \mathrm{O}$ and $\delta^{2} \mathrm{H}$, respectively. The results of the $\delta^{18} \mathrm{O} / \delta^{2} \mathrm{H}$ in Hamza et al. 's diagram is shown in Fig. 17. A few data fit the Global Meteoric Water Line with $d=10 \%$ and the others belong to a local palaeowater line with $d=-4.5 \%$. Four samples were located near the NSAS point.

From the evaluation of the isotope data and the results indicated in (Fig. 17), it is concluded that

1. The water samples of well nos. $6,12,13$ and 20 collected from the deep wells (more than $500 \mathrm{~m}$ deep and known in the literature as Nubian wells (Abdel Moneim 2005; Elewa et al. 2000, 2006, 2011) are mainly of Nubian sources (old water) and could be mixed with recharge from the Quaternary water. Also, water may be extracted from these wells not only from the Nubian sediments, but also from the overlaying Quaternary succession (the design of these wells is not available).

2. The other water samples (well nos. 1, 2, 3, 4, 5, 7, 8, 9, $11,18,19,21$ and 22) are located nearer to the Nile freshwater, indicating Quaternary water age.

3. The water samples collected from the shallow pits (sample nos. 14, 15, 16 and 17) are located much more nearer to the Nile water, revealing that water originated from the relatively recent fresh rain water.

\section{Conclusion and recommendation}

The study area covers part of Wadi Qena which is one of the largest wadis in the Eastern Desert of Egypt. The construction of a new desert road connecting Upper Egypt to the Red Sea has accelerated different forms of agricultural development in the wadi. Large numbers of wells were drilled in the wadi to extract water for cultivation activities, and this road provides wonderful opportunities to carry out hydrogeological and hydrogeochemical studies in such a remote area.

The sedimentary succession of Wadi Qena ranges from Paleozoic to Quaternary deposits. Large anticline represents one of the oldest systems in the stable shelf of Egypt of the Wadi Qena and plays a considerable role in the distribution, depth and thickness of the hydrogeologic unit in the area. The main groundwater bearing formations in the study area are the Quaternary aquifer that is formed of sand, gravel and boulders and the Nubian sandstone aquifer. The thickness of the Quaternary aquifers ranges between 20 and $100 \mathrm{~m}$ and increases toward the downstream of the wadi. Groundwater in the Nubian aquifer 
Table $7 \quad \delta^{18} \mathrm{O}$ and $\delta^{2} \mathrm{H}$ values for groundwater samples in the study area

\begin{tabular}{llll}
\hline Sample no. & Delta $^{18}$ O \%o vs. SMOW & Delta D \%o vs. SMOW & Well no. in Tables 2 and 3 \\
\hline 1 & -4.45 & -32.73 & Q2 \\
2 & -3.60 & -23.50 & Q3 \\
3 & -4.64 & -33.85 & Q4 \\
4 & -4.87 & -32.34 & Q5 \\
5 & -4.69 & -30.87 & Q6 \\
6 & -7.07 & -48.67 & N2 \\
7 & -5.51 & -40.87 & Q7 \\
8 & -4.90 & -24.78 & Q8 \\
9 & -5.48 & -33.15 & Q9 \\
10 & -5.77 & -33.22 & N3 \\
11 & -4.79 & -34.46 & Q10 \\
12 & -6.66 & -49.59 & N4 \\
13 & -6.95 & -52.33 & N5 \\
14 & -4.72 & -37.63 & Q17 \\
15 & -3.08 & -25.89 & Q18 \\
16 & -3.27 & -26.36 & Q19 \\
17 & -2.64 & -23.86 & Q20 \\
18 & -4.81 & -37.30 & Q11 \\
19 & -4.81 & -35.95 & Q12 \\
20 & -6.87 & -47.65 & N6 \\
21 & -5.16 & -38.27 & Q16 \\
22 & -5.05 & -40.28 &
\end{tabular}

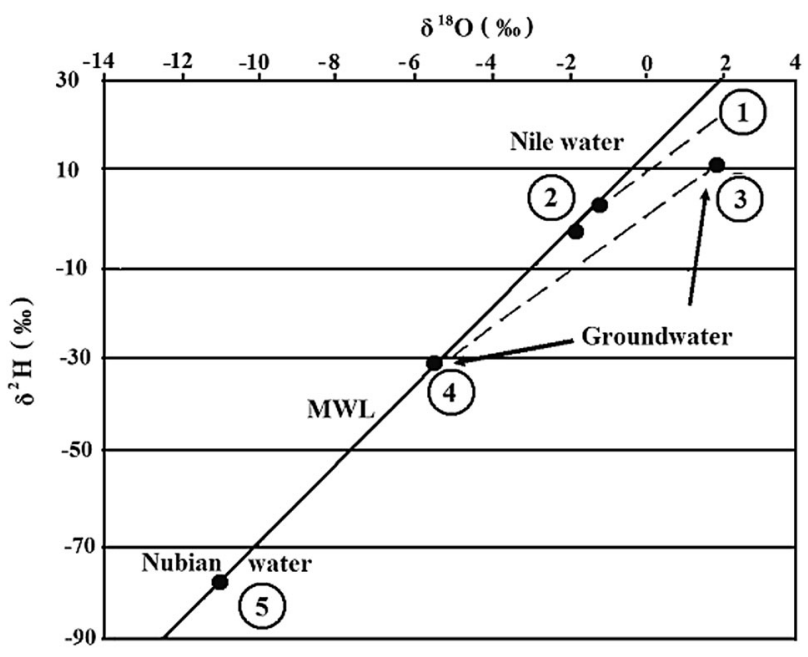

Fig. 16 Scheme of the application of the two-component mixing model with the correction of the $\delta^{18} \mathrm{O}$ values for evaporative isotope enrichment (Hamza et al. 2009)

occurs under confined condition (overlying the impermeable Quseir Shale). The depth to the Nubian aquifer ranges from 300 to $500 \mathrm{~m}$ below the ground surface with an average thickness of $350 \mathrm{~m}$ and decreases toward the north. The flow of the groundwater in the Nubian sandstone aquifer in Wadi Qena is defined to be from the northeast to southeast.

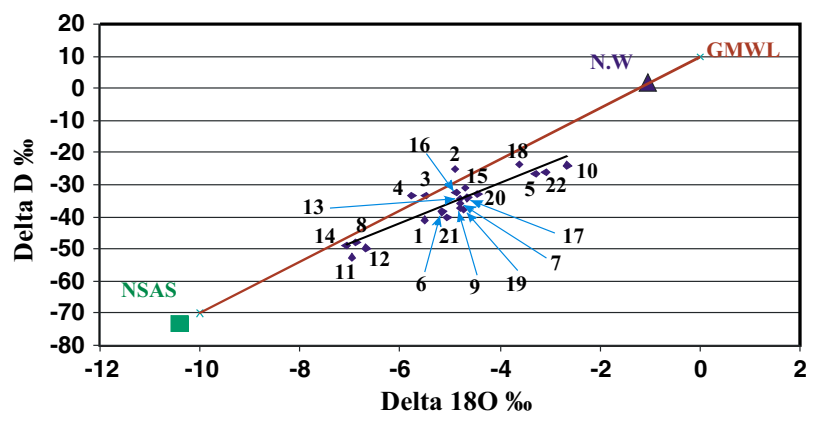

Fig. 17 Delta O-18 vs. delta D diagram for groundwater samples

The evaluation of the obtained results of the chemical analysis of the 26 samples [ 20 of the Quaternary aquifer system (QAS) and 6 of the Nubian sandstone aquifer system (NSAS)] indicates that the TDS in QAS varies from 1183 to $5506 \mathrm{ppm}$ and from 1496 to $1715 \mathrm{ppm}$ for the NSAS. It ranges between slightly saline and moderately saline for the QAS and slightly saline for the NSAS.

The evaluation of the hydrochemical parameters and presentations of the obtained data in the different diagrams indicated the meteoric water origin at the QAS and the marine origin in the NSAS aquifer. The evaluation indicated that the local terrestrial sources such as gypsum and anhydrite increases the sulfates content in groundwater. Accordingly, the continuous extraction of groundwater 
from the Nubian aquifer is expected to lead to water depletion of the aquifer as it is not a renewable aquifer.

Regarding the suitability of groundwater extracted from both QAS and NSAS for drinking and domestic uses, the result indicated that water in the area was not suitable for drinking purposes. The TDS, TH and the concentration of the cations and anions are higher than the allowable Egyptian drinking water standards.

The evaluation of the suitability of groundwater for irrigation purposes was discussed based on four common parameters, TDS, SAR, RSC and chloride content. The results showed that water from both aquifers (particularly the QAS) was suitable for irrigation of moderate to high salt-tolerant crops. Special arrangement should be made to improve the drainage condition in the area to increase crop productivity. The high concentration of TDS in the area is expected to lead to soil logging problem in the near future. Frequent leaching must be carried out to prevent serious salinity problems.

Regarding the suitability of water for the livestock and poultry, the 16 groundwater samples (10 of QAS and 6 of NSAS) had salinity ranging from 1000 to $2999 \mathrm{mg} / \mathrm{L}$. These are highly satisfactory for all classes of livestock and poultry, but may cause temporary and mild diarrhea in livestock not accustomed to such water, or watery dropping in poultry. Groundwater extraction from the Nubian aquifer is more favorable for livestock and poultry than water extracted from the Quaternary aquifer.

The values of the water saturation index in the study area indicated that groundwater was supersaturated with respect to iron mineral phases, whereas undersaturated with respect to the main carbonate minerals. Therefore, deposition of iron minerals and dissolution of the carbonates are expected.

The analysis of the isotope data $\left(\delta^{18} \mathrm{O}\right.$ and $\left.\delta^{2} \mathrm{H}\right)$ of the water samples from wells in the aquifers indicated that $\delta^{18} \mathrm{O}$ and $\delta^{2} \mathrm{H}$ values ranging from -7.07 to $-2.64 \%$ and from -52.33 to $-23.50 \%$ were yielded, respectively. The water samples of wells more than $500 \mathrm{~m}$ deep were mainly of Nubian sources (old water) and could be mixed by recharge from the Quaternary water. The other samples extracted water from the Quaternary water. The water samples collected from the shallow pits showed that water originated from the recent fresh rain water.

It is recommended that the following should be carried out for better management of the use of groundwater and crop productivity in the study area:

1. Extraction from the Quaternary aquifer should be stopped as it is not suitable for irrigation. Continuous pumping from the aquifer will cause soil logging in the near future and reduce crop productivity.
2. Extraction of water from the Nubian aquifer system should be managed properly (using sprinkler or drip irrigation) to avoid aquifer depletion, as the water is of marine origin and not renewable water.

3. Drainage condition should be improved continuously using the soil washing techniques to reduce the expected building up of soil salinity (soil logging) that will decrease the crop productivity.

4. Continuous monitoring of the water quality should be undertaken to evaluate the changes in the water quality in the area.

\section{References}

Abdallah AM, Darwish M, El Aref M, Helba A (1992) Lithostratigraphy of the Pre-Cenomanian clastics of north Wadi Qena, Eastern Desert, Egypt. Conf. Geology of the Arab World, Cairo University, Cairo, pp 255-280

Abdel Ghany KM (2011) Geo-environmental studies on Wadi Qena, Eastern Desert, Egypt. Using remote sensing dataand geographic information system. PhD Thesis, Geology Department, Faculty of Science, Al Azhar University, p 340

Abdel Moneim AA (2005) Hydrogeological conditions and land suitability for development on the area surrounding the proposed new road between Sohag and the Red Sea, Wadi Qena, Eastern Desert, Egypt. The fourth international conference on the geology of Africa, Assiut University 2:17-41

Aggour TA (1997) Impact of geomorphological and geological setting on groundwater in Qena-Safaga District. PhD Theses, Cairo University, p 320

Aggour TA, Sadek MA (2001) The recharge mechanism of some cases of the different groundwater aquifers, Eastern Desert, Egypt. Bull Fac Sci Mansoura Univ 28(1):43-78

ARE, Drinking Water Standard (2007) Guideline for drinking water quality standards. Ministry of Housing, Egypt

Assiut Univerity (2001) Groundwater resources and land use evaluation in the Southern Entrance of Wadi Qena, Easten Desert, Egypt. A project conducted by Assiut University and Supported by the Egyptian ministry of International Development

Awad GH, Ghobrial MG (1965) Zonal stratigraphy of the Kharga Oasis. Geol Surv Egypt Pap 34:77

Bandel K, Kuss J, Malchus N (1987) The sediments of Wadi Qena (Eastern Desert, Egypt). J Afr Earth Sci 6(4):427-455

Billings MP (1954) Structural geology, 2nd edn. PrenticHall Inc, NJ $514 \mathrm{p}$

CONOCO (1987) Geological map of Egypt, Scale 1: 500,000, Assiut and Beni Suef. The Egyptian General Petroleum Corporation, Cairo (EGPC), Egypt, Egypt

Craig H (1961) Isotopic variations in meteoric waters. Science 133:1702

Eaton FM (1950) Significance of carbonates in irrigation waters. Soil Sci 69(2):127-128

EGSMA (1983) Geological map of Gebel el 'urf quadrangles, Egypt, scale 1:250000. Geological Survey Egypt, Cairo

EGSMA (2006) Geological map of Abu had quadrangle. Egypt Scale $1: 100000$

El Gaby S, List FK, Tehrani R (1988) Geology, evolution and metallogensis for the pan-African belt in Egypt. In: El Gaby S, 
Greiling RO (eds) The Pan-African Belt of Northeast Africa and adjacent areas, pp 17-68

El kadi AI, Plummer NL, Aggarwal P (2010) NETPATH-WIN: an interactive user version of the mass-balance model, NETPATH. Department of Geology and Geophysics and Water Resources Research Center, University of Hawaii at Manoa, Honolulu, Hawaii 96822(808):956-6331

El Ramly MF (1972) A new geological map for the basement rocks in the eastern and south western desert of Egypt. Ann Geol Surv Egypt II:1-18

Elewa HH, Abu El Ella EM (2011) Numerical modeling for the Nubian aquifer development in Wadi Qena, Eastern Desert, Egypt. Egypt J Geol 55:105-125

Elewa HH, Fathy RG, Zaghloul EA (2000) Groundwater potential of the southern part of Wadi Qena basin, Eastern Desert of Egypt using remote sensing techniques. Egypt J Remote Sens Space Sci 3:135-152

Elewa HH, Fath RG, Zaghloul EA (2006) Possibility of the agricultural expansion based on land and water resources potentialities at the Southern Part of Wadi Qena, Central Eastern Desert, Egypt. Egypt J Soil Sci 46(2):153-174

FAO (1984) Water quality for irrigation and drainage. Paper No. 29. Rev 1, New York

Gheith H, Sultan M (2002) Construction of a hydrologic model for estimating Wadi runoff and groundwater recharge in the Eastern Desert, Egypt. J Hydrol 263:36-55

Ghorab MA (1956) A summary of a proponed rock stratigraphy classification for the upper cretaceous rocks in Egypt. Geol Soc Egypt

Ghorab MA (1961) Abnormal stratigraphic features in Ras Gharib oil fields. Third Arab Petroleum Congress, Alexandria, Egypt, pp $1-100$

Gomaa MA (1992) Hydrogeological studies between Quseir-Safaga area, Eastern Desert, Egypt. MSc Thesis Fac Sci Ain Shams University, p 150

Hamza MS, Aly AIM, Awad MA (2009) Estimation of recharge from Nile Aquifer to the desert fringes at Qena Area, Egypt. International Atomic Energy Agency, Vienna (Austria); International symposium on isotope techniques in water resources development and management; Vienna (Austria); 10-14 May 1999

Hem JD (1970) Study and interpretation of the chemical characteristics of natural water. U.S. Geological Survey Water Supply Paper, 1473p

Hendriks F, Kallenbach $\mathrm{H}$ (1986) The offshore to backshore environments of the Abu Ballas Formation of the SE Dakhla Basin (Western Desert, Egypt). Geologische Rundschau 75/2, Stuttgart, Germany

Hendriks F, Luger P, Bowitz J, Kallendbaah H (1987) Evaluation of the depositional environments of se-Egypt during the cretaceous and lower tertiary, Berliner Geowiss, Abh., (A) Berlin. 75 (1):49-82

Hermina M (1990) The surroundings of Kharga and Farafra oases. In: Said R (ed) The Geology of Egypt. Rotterdam: Balkema pp 259-292

Hermina MH, Klitzsch E, List FK (1989) Stratigraphic lexicon and explanatory notes to the geological map of Egypt 1: 500000. CONOCO Inc., Cairo, pp 1-251
Hume WF (1929) The surface dislocations in Egypt and Sinai, their nature and significance. Bull Soc Geograph Egypt 17:1-11

Issawi B, El Hinnawi M, Francis M, Mazhar A (1999) The Phanerozoic geology of Egypt. Egypt Geol Surv Spec Publ 76:1-462

Said R (1960) Planktonic foraminifera from the Thebes formation, Luxor, Egypt. Micropaleontology 16:227-286

Said R (1962) The geology of Egypt. Elsevier publishing Co., Amesterdam, New York 377p

Said R (1971) Explanatory notes to accompany the geological map of Egypt. Egypt Geol Surv 56:1-123

Said R (1975) The geological evaluation of the river Nile. In: Wendorf F, Marks AE (eds) problems in prehistory northern Africa and the Levant. Southern Methodist University Press, Dallas, Texas, pp 1-44

Said R (1981) The geological evaluation of the river Nile. Springer, New York 151p

Said R (1990) The geology of Egypt. Balkema, Rotterdam, pp 1-721

Sandford KS (1929) The pliocene and pleistocene deposits of wadi qena and of the Nile valley between Luxor and Assiut. Q J Geol Soc Lond 75:493548

Seleem (2014) Hydrogeological and geoelectrical studies on some areas in Wadi Qena, Eastern Desert, Egypt. PhD thesis submitted to Faculty of Science, Sohag University

Seleem EM, Abdel Monem AA, Zeid SA (2013) Geoelectrical soundings to delineate the Quaternary groundwater aquifer in the central part of Wadi Qena, Eastern Desert, Egypt. Egypt J Appl Geophys 12(2):191-207

Stern RJ, Hedge CE (1985) Geochronologic and isotopic constraints on late precambrian crustal evolution in the eastern desert of egypt. Am J Sci 285:97-127

Sulin VA (1962) Basis of classification of natural waters. Master Curves, Moscow

Sultan M, Sturchio N, Gheith H, Abdel Hady Y, El Anbeawy M (2000) Chemical and isotopic constraints on the origin of wadi el tarfa ground waters, eastern desert, Egypt. Groundwater 38:743-751

Taylor GG, Oza MM (1954) Geological Survey of India. Bull Series B 5:29

Thorweihe U, Heinl M (1993) Groundwater resources and management in southwest Egypt Catena supplement, biomineralization processes of iron and manganese. Berliner Geowissenschaft Abhand 2:99-121

U. S. Salinity Laboratory Staff (1954) Diagnosis and improvement of saline and alkali soils. Department of Agric, Handbook, Washington, DC, No 60, p 60

Wilcox LV (1948) The quality of water for irrigation use. U.S. Department of Agric, Technol Bull No. 962, pp 1-40

Wilmsen M, Nagm E (2012) Sequence stratigraphy of the lower Upper Cretaceous (Upper Cenomanian-Turonian) of the Eastern Desert, Egypt. Newslett Stratigr 46(1):23-46

Yehia A (2001) Study of general planning of the area surrounding the proposed road between Sohag and Hurgada. NARSSC, Cairo 104

Youssef MI (1957) Upper cretaceous rocks in Quseir area. Bull de L' Institut du Desert d' Egypt T VII(2):35-53 